\title{
The role of monetary incentives in prediction markets: a time series approach
}

Citation for published version (APA):

Wolk, K. L., \& Peeters, R. J. A. P. (2009). The role of monetary incentives in prediction markets: a time series approach. METEOR, Maastricht University School of Business and Economics. METEOR Research Memorandum No. 013 https://doi.org/10.26481/umamet.2009013

Document status and date:

Published: 01/01/2009

DOI:

10.26481/umamet.2009013

Document Version:

Publisher's PDF, also known as Version of record

\section{Please check the document version of this publication:}

- A submitted manuscript is the version of the article upon submission and before peer-review. There can be important differences between the submitted version and the official published version of record. People interested in the research are advised to contact the author for the final version of the publication, or visit the DOI to the publisher's website.

- The final author version and the galley proof are versions of the publication after peer review.

- The final published version features the final layout of the paper including the volume, issue and page numbers.

Link to publication

\footnotetext{
General rights rights.

- You may freely distribute the URL identifying the publication in the public portal. please follow below link for the End User Agreement:

www.umlib.nl/taverne-license

Take down policy

If you believe that this document breaches copyright please contact us at:

repository@maastrichtuniversity.nl

providing details and we will investigate your claim.
}

Copyright and moral rights for the publications made accessible in the public portal are retained by the authors and/or other copyright owners and it is a condition of accessing publications that users recognise and abide by the legal requirements associated with these

- Users may download and print one copy of any publication from the public portal for the purpose of private study or research.

- You may not further distribute the material or use it for any profit-making activity or commercial gain

If the publication is distributed under the terms of Article $25 \mathrm{fa}$ of the Dutch Copyright Act, indicated by the "Taverne" license above, 
Leonard Wolk, Ronald Peeters

The role of monetary incentives in prediction markets: a time series approach

RM/09/013

This working paper appeared as article:

Wolk, K. L., \& Peeters, R. J. A. P. (2012). Incentives in prediction markets. The Journal of Prediction Markets, 6(2), 47-58.

\section{GSBE}

Maastricht University School of Business and Economics

Graduate School of Business and Economics

\section{P.O Box 616}

NL-6200 MD Maastricht

The Netherlands 


\title{
The Role of Monetary Incentives in Prediction Markets: A Time Series Approach*
}

\author{
Leonard Wolk ${ }^{\dagger} \quad$ Ronald Peeters ${ }^{\ddagger}$
}

March 10, 2009

\begin{abstract}
Prediction markets serve as popular devices to aggregate beliefs and to assess market estimated probabilities. By looking at the interaction between real- and play-money prediction markets, this paper shows that traded volume has a significant positive effect on the probability of real- and play-money market cointegration. This indicates that the information aggregation process, eliminating individual traders' biases, operates even when not inducing truthful belief revelation with monetary incentives. The study is based on data from four markets covering the 2008 presidential election in the United States of America.
\end{abstract}

JEL Classification: D8; G1.

Keywords: prediction markets; incentives.

\section{Introduction}

A prediction market is a market where contracts on the outcome of a future event is traded. By aggregating dispersed beliefs into prices, prediction markets generate market estimated probabilities of a specified event becoming true. Due to design flexibility and prediction accuracy, prediction markets are gaining popularity, and has lead to corporations, including Google, Hewlett Packard (HP), Intel, and Microsoft, implementing such markets (Cowgill, Wolfers, \& Zitzewitz, 2008).

Microsoft implemented an experimental prediction market, with positive results, where participants could place bets on anticipated release dates or the number of software patches that would be released within a certain time frame (Kiviat, 2004). Also an experiment at HP shows promising results where prediction markets were able to outperform official sales forecasts in $75 \%$ of the markets (Chen \& Plott, 2002). While these examples indicate the

\footnotetext{
${ }^{*}$ The authors would like to thank Stephan Smeekes for advices on performing time series analysis.

${ }^{\dagger}$ Department of Finance, Maastricht University, P.O. Box 616, 6200 MD Maastricht, the Netherlands. Email address: l.wolk@finance.unimaas.nl. Corresponding author.

${ }^{\ddagger}$ Department of Economics, Maastricht University, P.O. Box 616, 6200 MD Maastricht, the Netherlands. Email address: r.peeters@algec.unimaas.nl.
} 
wide ranging areas where prediction markets can be successfully employed, the success often depends on the design and implementation of the specific prediction market (Leigh \& Wolfers, 2007).

One of the fundamental design differences is that between markets based on real- and play-money. On the one hand, in real-money markets monetary incentives are used to make market participants reveal their true beliefs about a future event. In play-money markets, on the other hand, no monetary incentives are present, and thus there is no financial gain of revealing one's true beliefs about a future event. Hence, in such a market, participants may manipulate prices without a financial loss. As a result, if market estimated probabilities are to be trusted, it is plausible to expect that real-money markets are to be preferred over play-money markets. National legislation, however, often restricts unlicensed operation of betting markets using real-money, and therefore, the use of play-money might be the only feasible alternative. Given the obstacle of operating a real-money market, can a play-money market be a viable alternative? Or, in other words, do play-money markets, operating without monetary incentives, behave similarly to real-money markets?

By testing for cointegration and long-run contract price adjustment in a bivariate setting, the purpose of this paper is to investigate the relationship between real- and play-money prediction markets. The data were obtained from two prediction market operators using the same trading platform, and thus consist of the exact same set of contracts. The study includes four markets covering the 2008 presidential election in the United States of America. The markets are: the democratic party nominee, the republican party nominee, the individual election winner, and the winning party.

Results show that a majority of the contracts are not cointegrated, and that traded volume positively affects the probability of cointegration. In other words, increased volume help the real- and play-money market to absorb and react to new information. This implies that, for contracts traded at low volumes the real- and play-money markets react differently to new information. While it is beyond this study to determine which of the two market types is superior at low volumes, this finding sheds doubt upon the marginal trader hypothesis, which argues that volume, to a large extent, is irrelevant to market efficiency. Further, we find that there is no indication of the real-money market driving the play-money market. Hence, evidence shows that monetary incentives do not foster information discovery.

The paper is outlined as follows: The second section discusses the relevant background to, and hypotheses of, the study. The third section discusses the data, method, and empirical findings of the econometric analysis. The fourth section presents the conclusion of the econometric analysis and the final section discusses the findings. 


\section{Background}

\subsection{Introduction to Prediction Markets}

A prediction market is a financial market where contracts, whose values are tied to the outcome of a future event, are traded (Wolfers \& Zitzewitz, 2004). The idea is that the price of a contract aggregates information that different market participants hold (Forsythe, Nelson, Neumann, \& Wright, 1992).

Consider a commodity future, such as a three months contract on crude oil. The price of this future reflects current beliefs on the value of oil three months from now. A prediction market is similar to a futures market, with the difference being that prediction markets rely on current events, such as political elections instead of an underlying asset that is to be delivered some time from now. The advantage of a prediction market is that many events have an outcome that can be coded as a binary event, either a politician is elected or he is not for example. This makes it possible to specify a contract that pays at expiry e.g. 100 if the politician is elected and zero otherwise. This gives the contract a possible price range between zero and 100. A notable feature of such a contract therefore is that the price divided by 100 reflects the market estimated probability of the event becoming true. This type of contract can of course also be applied on top of the futures market in the sense that one can specify a contract paying 100 if the price of oil at date $X$ is above $\$ 200$, and zero otherwise. The price would then reflect the probability that the price actually will exceed $\$ 200$ at date $X$. Such a contract is often referred to as a winner-takes-all contract (Wolfers \& Zitzewitz, 2004).

The idea traces back to 1945 when Hayek asserted that "in a system where the knowledge of relevant facts are dispersed among many people, prices can act to coordinate the separate actions of different people" (Hayek, 1945, p. 526). In a ground breaking study, motivated by the hypothesis of Hayek, Forsythe et al. (1992) set up an experimental prediction market, the Iowa Political Stock Market (IPSM), with the aim to predict the vote shares of the U.S. presidential election in 1988. There were three contracts covering, the republican nominee, the democratic nominee, and a final contract covering all other candidates. The results of the experiment are astonishing, and the prediction errors for the three contracts were $0.0 \%$ points, $0.2 \%$-points and $0.6 \%$-points respectively. The IPSM results do not only impress when compared to the actual outcome, but also when compared to election polls. Forsythe et al. (1992, p. 1150) note that when comparing the IPSM to major polls, the data "suggests that opinion polls are excessively volatile, certainly more so than can be attributed to sampling error alone".

Forsythe et al. (1992) argue that the accuracy of the IPSM can be attributed to the existence of marginal traders. A marginal trader is defined as a trader who does not suffer 
from biased judgments and would thus trade on arbitrage opportunities in the market. Hence, marginal traders benefit from the existence of biased traders who in turn create arbitrage possibilities. By comparing the investments of marginal and biased traders, Forsythe et al. (1992) find that marginal traders earn a higher return on their investments than a nonmarginal trader due to the lower judgment bias.

In addition to accuracy in prediction, Berg and Rietz (2003) highlight several additional advantages of prediction markets. First, unlike polls, the markets are updated continuously. Hence, the market price at any point in time will reflect the aggregated beliefs at that point in time. Second, the use of prices significantly simplifies the aggregation of information that would otherwise be difficult to quantify. Third, evidence suggests that individual biases are overcome in the aggregate market.

Individual judgment biases often arise through wishful thinking, or in other words through an optimistic bias, which implies that a market participant is overestimating the probability of a desired outcome to occur (Forsythe, Rietz, \& Ross, 1999). This means that a market participant will buy and sell contracts at prices that are different from what an unbiased trader might have done. Although many sources for such behavior can exist, Forsythe et al. (1999) limit their investigation to the false consensus effect and the assimilation-contrast effect. The false consensus effect is a bias where an individual tends to overestimate the proportion of other people within a population sharing his beliefs. The assimilation-contrast effect leads the market participant to react overly positive to positive news about a desired outcome. Both effects lead market participants to overestimate the price of a contract for a desired candidate, which in turn might affect contract prices of the market. Although possible, it is not necessary that the biases will lead to changed market prices (Forsythe et al., 1999).

Another source of mispricing is the presence of mistakes. Mistakes, in contrast to biased beliefs, cannot be economically motivated (Forsythe et al., 1999). A mistake can occur on either the market making or the price taking side of the market. In both cases, however, it involves foregoing a sure profit. In a study reviewed by Forsythe et al. (1999), evidence suggests that market makers both are more experienced and make less mistakes than other traders. Through mistakes, arbitrage opportunities are created, which means that the price of a bundle covering all possible outcomes has a price different than the payout rate from one event becoming true. The price deviation from the payout rate can be both positive and negative. Whether or not arbitrage opportunities persist in a market is unclear. On the one hand, in the IPSM arbitrage possibilities did not seem to endure. While, on the other hand, laboratory experiments have shown that mispricing in markets can endure throughout an experiment (Forsythe et al., 1999).

Prediction markets do regrettably not come without potential problems. Frequent criticism involves price manipulation. The possibility to manipulate a market depends on the 
liquidity of the market; the thinner the market, the less money is required to manipulate it (Wolfers \& Zitzewitz, 2004). Wolfers and Zitzewitz (2004, p. 119) report that "[t]here have been several known attempts at manipulation of these markets, but none of them had much of a discernible effect on prices, except during a short transition phase". This observation supports the argument that the existence of marginal traders, as argued by Forsythe et al. (1992), indicate that price manipulation would be recognized by marginal traders as arbitrage opportunities and thus quickly acted upon. Hanson (2006) argues that possibilities to manipulate prices are not exclusive to prediction markets, but can occur in other asset markets as well. The author, however, acknowledges that manipulation of prices that are used as a direct influence in decision-making, so called decision markets, may have severe consequences on the outcome.

A further problem became evident when the Defense Advanced Research Projects Agency (DARPA) prediction market project caught the attention of the public. The DARPA market was a U.S. government funded project to evaluate the use of prediction markets in predicting geopolitical trends for policy purposes (Hanson, 2007). Results of the initial test phase were promising, and significant progress on the use of combinatorial markets was done. This led to the project receiving additional financing (Hanson, 2006). A turn came in the aftermath of the attacks on September 11, 2001. By portraying the project as an opportunity to profit from terrorism (Wolfers \& Zitzewitz, 2004), the government halted funding for the project and forced the project to close down (Hanson, 2006), even though contracts directly related to terrorism were beyond the scope of the project (Wolfers \& Zitzewitz, 2004).

\subsection{Differences Between Real- and Play-Money Markets}

Prediction markets can be designed in a wide variety of ways. One of the more common distinctions is that between markets based on real- and play-money. The difference being whether or not monetary incentives are present. This means that in a play-money market, in contrast to a real-money market, participants do not bear a financial risk from trading (Rosenbloom \& Notz, 2006).

Read (2005) argues that behavior is affected in three ways as the result of monetary incentives. First, the introduction of incentives may affect the cognitive exertion. This means that, without being given a reward for a task, the cognitive effort may be lower. In other words, incentives increase the stakes involved in a decision making process and thereby induce people to increase their cognitive effort. Hence, increased cognitive exertion implies that there would be stronger incentives for spending more time on the decision itself, which in turn implies that monetary incentives drive information discovery.

Second, incentives might affect the motivational focus. Read (2005) argues that since participants might have differing levels of intrinsic motivation for doing any task, monetary 
incentives can shift the motivational focus of the participants from intrinsic motivation to extrinsic motivation. For an experimenter this can be a positive effect, even though the overall motivation is lower, since it makes experimental evidence easier to interpret.

Third, and last, is the effect of an incentive as an emotional trigger. This effect is exemplified through the finding that agents are either unable to correctly predict their own response to a stimuli or cannot reproduce it at all. This has an important implication for the comparison between real- and play-money markets, since it highlights the problem that participants might not be able to anticipate the effect of a trade without the use of real-money. Read (2005, p. 272) argues that "[t]he potential loss of real money, therefore, probably can elicit a visceral reaction that can neither be experienced nor predicted in its absence".

In a survey by Frey and Jegen (2001), the authors present irresistible evidence showing how monetary incentives can crowd out intrinsic motivation under certain circumstances. Frey and Jegen (2001) argue that an incentive which is perceived as an attempt to control an individual will crowd out intrinsic motivation whereas a supportive incentive will have the opposite effect. Whether the net effect is positive or negative depends on the relative size of the two effects. Hence, it could be that participants in the play-money market are motivated by an intrinsic motivation to reveal their true beliefs, and thus the importance of monetary incentives is diminished.

Apart from incentives, there are also other differences. Rosenbloom and Notz (2006) note that traded volumes in real- and play-money market differ quite substantially. The authors argue that higher volumes are associated with higher accuracy, which would favor play-money markets over real-money markets. Forsythe et al. (1999) argue to the contrary. According to a laboratory study, the existence of marginal traders will bring the market into an efficient state even at low volumes. The result is similar to the findings from the original IPSM where marginal traders were seen as key to the market accuracy (Forsythe et al., 1992).

A second important difference concerns the ability to accumulate funds to trade with. In a real-money market a participant can add money as he sees it fit. In a play-money market, on the other hand, the participant is endowed with a certain amount of play-money upon the creation of his account. The participant cannot buy additional funds, hence, "the only way to amass wealth in a play-money exchange is by a history of accurate predictions" (Servan-Schreiber, Wolfers, Pennock, \& Galebach, 2004, p. 244).

A third difference, while important for market design, might not influence trading behavior, are legal differences on the national level. In many countries, it is often difficult, if not impossible, to obtain licenses to operate a real-money prediction market due to restrictions on gambling (Wolfers \& Zitzewitz, 2004). By operating a play-money market, it is possible to get around the legal problems of a real-money market. 


\subsection{Evidence from Previous Studies}

While most studies involve prediction markets where contracts are traded with real-money, Servan-Schreiber et al. (2004) compare the predictive power of real- and play-money for 208 American football games. The authors examine how well the pre-game favorite, determined by the market price, match the winner of the game. The real-money market, was correct in $65.9 \%$ of the games and the play money market was correct in $66.8 \%$ of the games (ServanSchreiber et al., 2004).

In a study by Rosenbloom and Notz (2006), a sequential probability ratio test is applied to investigate the differences between real- and play-money markets. The study was performed on contracts from team sports as well as the Dow Jones Industrial Average (DJIA) stock index. The study concludes that, while overall the real-money market outperforms the playmoney market, there are differences between the sports and financial market contracts. In the sports market, the differences in accuracy are statistically insignificant whereas in the DJIA market, the real-money market is significantly better than the play-money market. Rosenbloom and Notz (2006) speculate that the reason might be the widely available odds that are published for sports markets. Such odds are unavailable for the DJIA, which may contribute to the differences in pricing between the two market types.

In a third study, Luckner, Weinhardt, and Studer (2006) set up two experimental markets, one based on real-money and one based on play-money. Participants bet on which team would be leading the German soccer league at the end of the first half of the season 2005/2006. The authors then compare the two markets by looking backwards at the average absolute deviation (AAD) from the half season outcome. The study reveals that the play-money market AAD was closer to the outcome, as compared to the real-money market AAD, in 37 of the 50 trading days. This finding led the authors to conclude that the play-money market outperforms the real-money market. A problem arises through the fact that the observations in the study are not independent of each other. After all, the AAD of a given trading day is not independent of the $\mathrm{AAD}$ of previous trading days in the same market. As a result, it is not appropriate to treat the 50 trading days as 50 independent observations. Instead, it is possible to look at each market as a single observation; i.e., one observation describing the real-money market, and one observation describing the play-money market. The problem for the study in question is however that the number of observations, one for each market type, is below the number required to draw statistically significant conclusions.

\subsection{Hypotheses about Real- and Play-money Markets}

A common characteristic for all three prior studies is that they ignore the time dimension of the relationship between the real- and play-money markets. Accordingly, the purpose of this paper is to investigate the real- and play-money market from a time series perspective. 
The theoretical framework has highlighted several differences between the two market types. These differences are reflected by the following hypotheses:

Hypothesis 1 The sum of the contract prices for each market equals the payout rate of the same market.

Hypothesis 2 The real- and play-money markets are cointegrated.

Hypothesis 3 The real-money market drives the play-money market.

Hypothesis 4 The contract volume does not affect the probability of a real-and play-money contract pair being cointegrated.

The first hypothesis concerns the existence of arbitrage in the markets. Arbitrage exists at any time when the sum of all contract prices within a market differs from the payout rate. Given the media exposure and public interest in the primary election process in the United States of America, we expect arbitrage, on average, to be non-existent.

The second hypothesis argues that since the markets are continuously updating their prices, which are based on the beliefs of the market participants, the real- and play-money market should be cointegrated. In other words, if participants base their decision making on the same information, the markets should move together.

Read (2005) argues that monetary incentives strengthen the cognitive exertion. This indicates that the incentive to conduct extensive information discovery is stronger in the realmoney market than in the play-money market. Hence, the third hypothesis specifies that the real-money market is expected to drive the play-money market.

The fourth hypothesis concerns the effect of volumes. If marginal traders are present, volume should not affect the cointegration between the real- and play-money markets.

\section{Empirical Study}

\subsection{Data Description and Collection}

To investigate the difference between real- and play-money in prediction markets, data on the 2008 presidential election and its primaries in the United States of America was collected. The study is delimited to four markets: the democratic nomination market, the republican nomination market, the individual election winner, and the winning party. All contracts are of the winner-takes-all type. The time span analyzed varies slightly between the different markets. An overview can be found in Table 1; a complete list of the contracts can be found in Appendix A.

The real-money market is operated by Intrade and the play-money market is operated by the Financial Times, under the name FTPredict. ${ }^{1}$ Both operators run on the Intrade

\footnotetext{
${ }^{1}$ http://www.intrade.com and http://www.ftpredict.com.
} 


\begin{tabular}{lcc}
\hline Market & Time Span $(\mathrm{dd} / \mathrm{mm} /$ yyyy $)$ & No. of Contracts \\
\hline Democratic Nomination & $18 / 10 / 2007-24 / 05 / 2008$ & 28 \\
Republican Nomination & $19 / 09 / 2007-24 / 05 / 2008$ & 33 \\
Winning Individual & $11 / 09 / 2007-24 / 05 / 2008$ & 18 \\
Winning Party & $10 / 02 / 2007-24 / 05 / 2008$ & 3 \\
\hline
\end{tabular}

Table 1: Overview of the markets.

platform and offer the exact same contracts for each market analyzed in this paper, with the only difference being the contract creation dates and size of commission fees. The problem of different creation dates for contracts within a market is solved by adjusting the initial date of analysis in each market to the date where both markets started to offer a set of contracts covering all possible outcomes.

The data is publicly available through the websites of the respective market operator and was downloaded on May 25, 2008. It is in daily format, and includes observations until May 24,2008 . For each contract there are five variables that are recorded on a daily basis: opening price, closing price, daily low, daily high, and daily volume. This study considers the daily closing prices and the daily volumes.
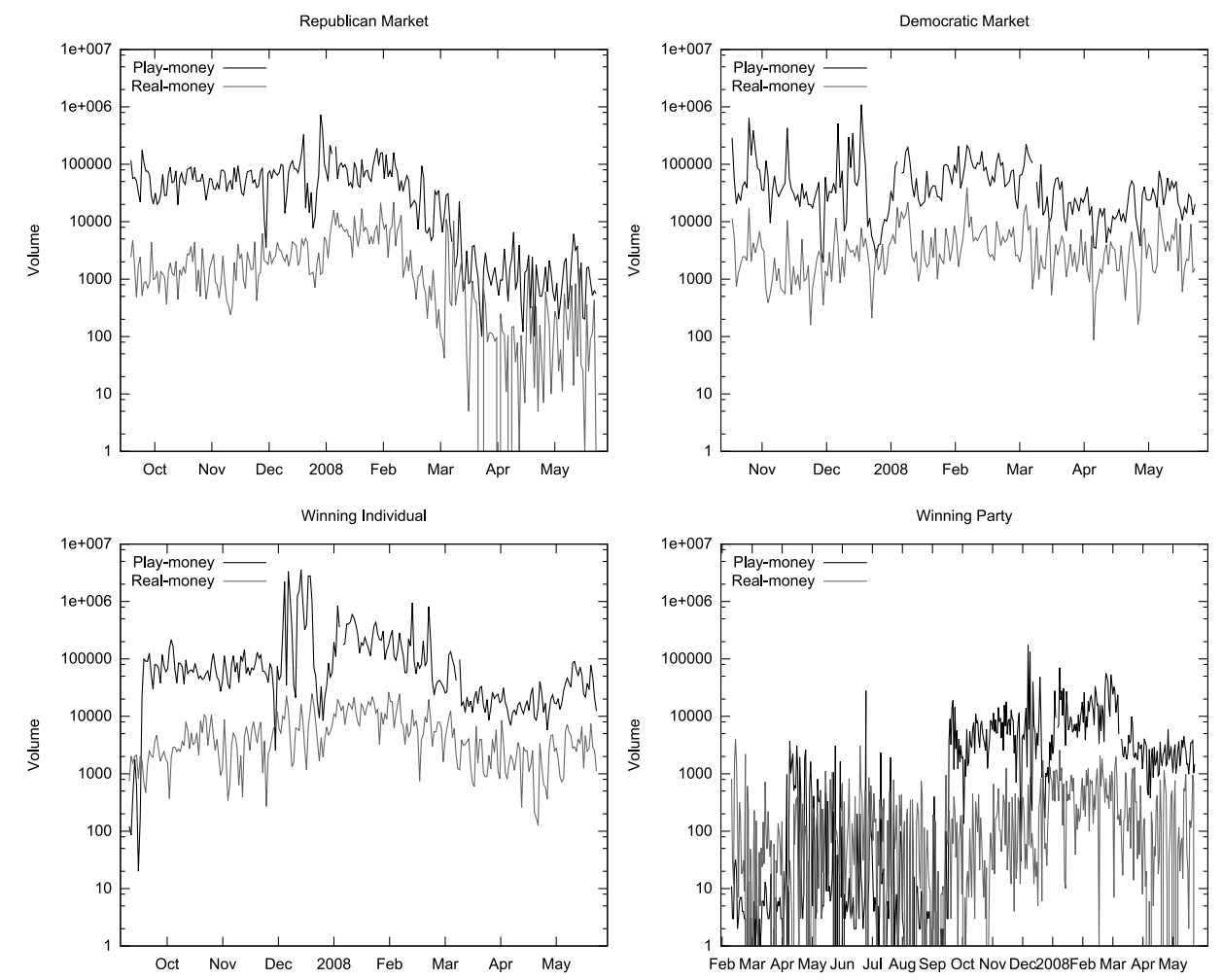

Figure 1: Total volumes traded in the four markets (daily).

Both markets use equal price ranges, ranging from 0 to 100 , with a precision of one decimal. In the real-money market a price of 100 corresponds to a price of $\$ 10$. A market 
participant can refill his account or withdraw money from it at any time. In the play-money market each new account is endowed with $\$ 10,000$ of play-money. The difference in monetary costs of obtaining credit to trade for is visible in Figure 1 where the total volume of the realand play-money market are graphed together. The play-money market volumes surpass the real-money volumes substantially. ${ }^{2}$ Important to note when reading the graph is that it uses a logarithmic scale.
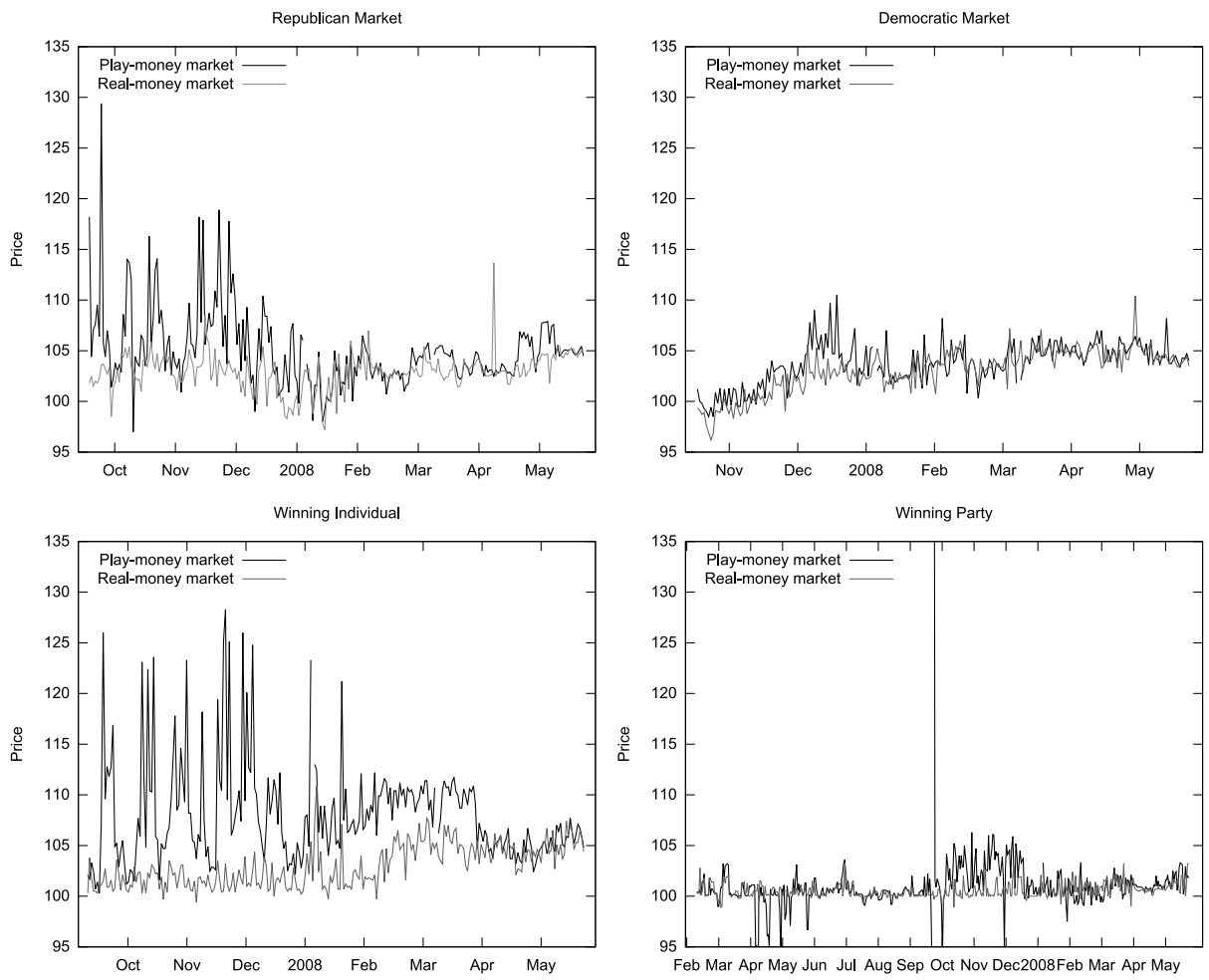

Figure 2: Sum of contract prices in the different markets.

Consider the sum of all contract prices in a market. This is the price one would have to pay, to buy a complete bundle of contracts that cover all possible outcomes in the market. One would expect this price to be close to 100, which equals the payout rate for an event that becomes true. If the total price exceeds 100, one can make a sure profit by selling a bundle of all contracts and thus only committing oneself to pay 100 upon expiry. If, on the other hand, the total price is below 100, one can buy a bundle and make a sure profit. As can be seen in Figure 2, the total market price, almost constantly exceeds 100 for both the real- and play-money markets. A reason could be that contracts cannot take a price below 0.1. ${ }^{3}$ Consider e.g. the democratic nomination market which has 28 contracts. Given that

\footnotetext{
${ }^{2}$ On average over the market specific time period, the ratio of play-money volume divided by real-money volume is for the democratic market: 15.67; republican market: 19.60; individual winner: 30.90; and winning party: 18.53 .

${ }^{3}$ It is highly improbable that someone will sell a contract at a price of 0.0 . Hence, the lowest price that a
} 
at the time of the data retrieval only two candidates remained in the race, there must be 26 contracts with a price of 0.1 , or close to this value. This means that the total market price can be overestimated by at least 2.6 units, without there being real arbitrage opportunities. In addition, there is a possibility that there are not enough buyers willing to trade contracts that cover candidates who have dropped out. This would mean that the price might not even reach its minimum of 0.1 and thus contribute to the overpricing of the complete bundle.

To illustrate this issue, Figure 3 shows the summed price of Obama and Clinton, covering only the time period for which they were the only remaining candidates in the race. ${ }^{4}$ It is notable to see that the mean aggregate price of the two candidates, in both markets, is approximately $99 .^{5}$ In contrast to the complete market, the Clinton-Obama bundle price is slightly less than 100 on average, which can be explained by a sort of interest rate argument. By giving up 99 now, one can get 100 sometime in the future. The price of the complete bundle therefore suggests that the markets fail to adequately adjust the prices for candidates who are no longer competing for the nomination. This in turn suggests that the more contracts there are in a market, the more distorted the price of the complete bundle will be, due to the inadequate adjustment process of the prices.

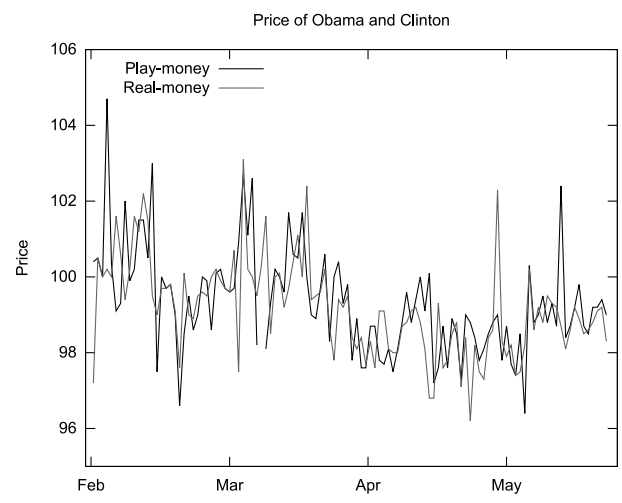

Figure 3: Aggregate price of the Clinton and Obama contracts.

The outcome of the democratic nomination market, the individual winner market, and the winning party market were uncertain for the whole time span included in the study. In the republican nomination market on the other hand, John McCain declared himself a winner already on March 5, 2008. ${ }^{6}$ This made it highly improbable for any other candidate to win the nomination and thus the uncertainty surrounding the election process diminished. At this point the only factors which can lead to a different outcome are highly improbable events such

contract can take is zero plus the minimum tick size, which is 0.1 .

${ }^{4}$ John Edwards, the third major democratic candidate, dropped out on January 30, 2008. Hence, the period covered in this section is January 31, 2008 - May 24, 2008.

${ }^{5}$ Specifically, the average real-money price is 99.2 and the average play-money price is 99.3 .

${ }^{6}$ New York Times Article: Big Wins for Clinton in Texas and Ohio; McCain clinches Race as Foe Concedes, published on March 5, 2008, retrieved from http://www.nytimes.com/2008/03/05/us/politics/05primary.html. 
as death. The republican time series was therefore divided into two separate sub-samples, as is shown in Table 2. This division allows for an additional analysis of the Republican nominee market after the point where John McCain secured the nomination.

\begin{tabular}{ccl}
\hline Period & Time Span $(\mathrm{dd} / \mathrm{mm} /$ yyyy $)$ & Period Covers \\
\hline 1 & $19 / 09 / 2007-05 / 03 / 2008$ & Nomination period with multiple candidates \\
2 & $06 / 03 / 2008-24 / 05 / 2008$ & Nomination period with a single candidate \\
\hline
\end{tabular}

Table 2: Election period for the republican nominee divided in two sub-samples.

\subsection{Design Differences}

While the real- and play-money markets are very similar, there are a few design differences that may have important implications for the comparison of the two market types. These differences concern the present implementation of the markets used in this study, and thus cannot be generalized to other real- and play-money markets. Hence, these differences exist in addition to the ones discussed in the theoretical framework.

First, there is a difference in traded volume, observed in Figure 1, which arises from the price of a contract. While in the play-money market every trader is endowed with $\$ 10,000$ of play-money, each contract in the real-money market costs between $\$ 0$ and $\$ 10$. It is, as discussed in the theoretical framework, possible that higher volumes are associated with higher accuracy.

A second difference concerns commission fees. While both markets incorporate commission fees, their size vary slightly. In the play-money market the commission fees amount to play$\$ 0.05$, and in the real-money market, they vary from $\$ 0.00$ to $\$ 0.05$ depending on the type of transaction. A further difference is that the real-money market incorporates a fixed expiry fee of $\$ 0.10$ (1\% of the payout rate) for contracts that result in a positive profit (i.e. a participant holds a winning position). The implementation of transaction costs in the play-money market is an attempt to mimic trading behavior of the real-money market.

A third implementation difference is that the play-money market includes a ranking that shows the performance of a participant in relation to other participants. ${ }^{7}$ This creates an extrinsic motivation to participate and to reveal one's true beliefs in order to rise through the rankings. Such a ranking is not available in the real-money market. To measure the impact of the differences highlighted here one will have to conduct a series of experiments.

\subsection{Time Series Analysis}

By applying a time series approach to the study of real- and play-money prediction markets, one is able to look at the cross effect of the different markets over time and whether contracts of

\footnotetext{
${ }^{7}$ See http://www.ftpredict.com/aav2/leaderBoard/ for an example.
} 
the different markets move together or not. By using lagged values of a variable to explain the current value of the same variable, one treats the variable as a priori endogenous (Lütkepohl, 1999), which is a common occurrence in time series analysis. This technique requires one to determine the number of lags to include in the analysis. The Akaike information criterion (AIC) is used for this purpose.

The study, investigates whether there is causality as well as cointegration present in the different markets. Cointegration occurs when there is a linear combination between at least two non-stationary variables. In this sense, cointegration refers to a long-run equilibrium between two or more variables. ${ }^{8}$ Causality can be determined when there either is a trend in one variable to adjust toward a second variable, or when past values of one variable can explain the present value of a second variable. We look at causality by using two different techniques, first by looking at adjustment trends between two variables in a vector error correction framework and then by applying a Granger causality test to look for serial correlation across the two markets.

\subsubsection{Testing for Stationarity}

Cointegration requires all variables to be integrated of the same order (Enders, 2004). This means that for the bivariate analysis of real- and play-money markets, both contracts of each pair has to be non-stationary, or integrated of order one. Stationary and non-stationary time series exhibit several important differences in their characteristics. While a stationary process has a constant mean in the long-run, this is not the case for a non-stationary process. Hence, as time approaches infinity, the variance of a non-stationary time series also approaches infinity (Enders, 2004).

For the purpose of detecting a non-stationary time series, the Augmented Dickey-Fuller (ADF) test is used, as discussed by Enders (2004). The ADF test allows for an arbitrary number of lags to be included, with the null hypothesis of a unit root being present against the alternative hypothesis of no unit root. When no unit root is present, a variable is said to be integrated of order zero, which in other words means that the variable is stationary. Hence, the value at time $t$ is independent of the value at time $t-1$. When, on the other hand, a variable's value at $t$ depends on the value at $t-1$, it is said to be non-stationary, or integrated of order one.

The ADF test is applied on the levels as well as on the first differences of the variables. By applying the test on the first differences, one can determine whether a time series contains more than one unit root. A summary of the results is available in Table 3 and full results are in Appendices B.1 and B.2.

\footnotetext{
${ }^{8}$ Equilibrium in the econometric sense implies that the variables have similar trends and the concept thus is distinct from the notion of equilibrium in economic theory.
} 


\begin{tabular}{ccccc}
\hline \multicolumn{2}{c}{ ADF tests on levels } & & \multicolumn{2}{c}{ ADF tests on first difference given I(1) } \\
\cline { 1 - 2 } \cline { 1 - 1 } Order & Number of Pairs & & Order & Number of Pairs \\
\hline 0 & 4 & & 0 & 29 \\
1 & 30 & & 1 & 0 \\
$D$ & 11 & & $D$ & 1 \\
\hline
\end{tabular}

Table 3: Summary of ADF unit root tests at the $5 \%$ level. (D: different orders for the two variables).

In total there are 115 contract pairs. ${ }^{9}$ Forty-five of the contract pairs exhibit a price change in both variables, meaning that they respond to information changes in the market. Since it is only interesting to consider pairs where both contracts react to information in the market, all but 45 pairs are excluded from further analysis. The ADF test results further narrow down the number of suitable contract pairs to 30, and by the first difference ADF test one additional contract pair is excluded due to the possibility of multiple unit roots.

\subsubsection{Cointegration Tests}

Having determined the contract pairs where both contracts are integrated of order one, and the first differences integrated of order zero, one can test for evidence of cointegration. If cointegration is evident, it means that the real- and play-money contracts are moving together and thus reacting similarly to information in the market. To test for cointegration we follow the Johansen procedure and thereby determine a trace statistic to test the null hypothesis of at least $k$ cointegrating relationships between $n$ variables, where $k \in\{0,1, \ldots, n-1\}$, against the alternative hypothesis of $k+1 \leq n$ cointegrating relationships (Enders, 2004). In other words, consider a scenario of two non-stationary variables that one suspects to be cointegrated. With two variables there can be no or one cointegrating relationship. The Johansen procedure, based on the trace statistic, tests whether there is no, or at least one cointegrating relationship present.

\begin{tabular}{lc}
\hline No. of C.E. & Number of Pairs \\
\hline None & 9 \\
At least 1 & 18 \\
(Reject both) & 2 \\
\hline
\end{tabular}

Table 4: Summary of cointegration test results at the $5 \%$ level. (C.E.: cointegrating equations).

By conducting a bivariate cointegration test between the real- and play-money contract of each pair, the aim is to detect whether the two markets move together. A summary is available in Table 4, which shows that a large fraction of the contract pairs are cointegrated. However, it is important to note that a significant portion of the pairs cannot be determined to be cointegrated. The full test results are available in Appendix B.3.

\footnotetext{
${ }^{9}$ The 115 pairs are divided as follows: 28 for the democratic nominee, $2 \times 33$ for the republican nominee (divided into two sub-samples.), 18 for the individual winner, and 3 for the winning party.
} 


\subsubsection{Causality Tests}

The ADF tests show that many of the contract pairs are integrated of different orders indicating that the real- and play-money contracts do not move together. In addition, the cointegration tests of the contract pairs that are integrated of the same order provide inconclusive results: approximately $30 \%$ of the contract prices are determined not to move together in the two markets. These results suggest that the two markets to a large extent react differently on information in the market. Given these differences, it is still important to analyze whether there is one market that drives the other market, or in other words, if there is causality. We restrict attention to the contract pairs that are integrated of order one, i.e. the same set of pairs that are present in the cointegration tests, since otherwise there is no long-run adjustment process possible.

Since the variables are non-stationary, we construct a bivariate vector error correction model (VECM). A VECM is similar to a vector autoregression (VAR) that is used for stationary processes, but in addition contains an error correction term to correct for the nonstationarity. In a VAR, all variables are assumed to be endogenous, which as a result allows a variable to be explained by its own lagged values. This means that a VAR, with $k$ lags, takes the following form:

$$
y_{t}=A_{1} y_{t-1}+\cdots+A_{k} y_{t-k}+u_{t}
$$

While the VAR model is general enough to model non-stationary and cointegrated variables, the cointegration is not made explicit (Lütkepohl, 1999). A VECM provides a convenient solution to this problem by introducing an error correction term, as well as modeling the first difference instead of the levels, in order to remove any stochastic trend of the data. While explaining the VECM deserves a section of its own, it is beyond the scope of this paper, and we will therefore focus on the bivariate error correction model only. Consider the following bivariate VECM between a play-money contract, denoted by the subscript $p$, and the real-money contract, denoted by the subscript $r$ with $k$ lags, adapted from Enders (2004):

$$
\begin{aligned}
& \Delta p_{p, t}=A_{10}+\alpha_{p}\left(p_{r, t-1}-\beta p_{p, t-1}\right)+\sum_{\ell=1}^{k} A_{11}(\ell) \Delta p_{p, t-\ell}+\sum_{\ell=1}^{k} A_{12}(\ell) \Delta p_{r, t-\ell}+u_{p, t} \\
& \Delta p_{r, t}=A_{20}-\alpha_{r}\left(p_{p, t-1}-\beta p_{r, t-1}\right)+\sum_{\ell=1}^{k} A_{21}(\ell) \Delta p_{p, t-\ell}+\sum_{\ell=1}^{k} A_{22}(\ell) \Delta p_{r, t-\ell}+u_{r, t}
\end{aligned}
$$

where $\alpha_{p}\left(p_{r, t-1}-\beta p_{p, t-1}\right)$ and $-\alpha_{r}\left(p_{p, t-1}-\beta p_{r, t-1}\right)$ are the respective error correction terms; The first summation in the VECM equations, represents the coefficients for the $\ell$ number of lags included in the model from the play-money market, and the second summation represents the same, but for the real-money market. The $u_{p, t}$ and $u_{r, t}$ terms represent the disturbance term of the model. $A_{10}$ and $A_{20}$ are the intercepts of the error correction model. Since the 
VECM is in first differences, any stochastic trend is isolated in the two $\alpha$ :s, which can be seen as a speed of adjustment factor of one variable to the other, and vice versa (Enders, 2004). Hence, a large value of $\alpha_{p}$, indicates that the play-money market is responding to the real-money market in the long-run. The opposite is true for small values of $\alpha_{p}$ (i.e. close to zero). By testing the restrictions of $\alpha_{p}=0$ and $\alpha_{r}=0$, one makes an inference about the long-run causality between the two markets.

The results can be grouped into four categories: First, the play-money market drives the real-money market. Second, the real-money market drives the play-money market. Third, both markets drive each other. And, fourth, none of the markets drive each other. The results are presented in Table 5, with full results available in Appendix B.4. The results do not give clear implications for interpretation, but it is worth noting that in about two-thirds of the contract pairs one market drives the other. What is unclear however, is the direction in which this occurs. Dividing the results per market, indicates that the long-run correction direction might be market specific.

\begin{tabular}{lcccccc}
\hline & \multicolumn{2}{c}{ Overall Results } & & \multicolumn{3}{c}{ Market Specific Results } \\
\cline { 2 - 3 } \cline { 5 - 7 } Category & No. of Contracts & & Dem & Rep & Ind & Party \\
\hline Play-money drives real-money & 7 & & 4 & 0 & 3 & 0 \\
Real-money drives play-money & 12 & & 1 & 4 & 6 & 1 \\
Both markets drive each other & 2 & & 1 & 1 & 0 & 0 \\
No market drives the other & 9 & & 2 & 4 & 2 & 1 \\
\hline
\end{tabular}

Table 5: VECM $\alpha$-restrictions (5\% level).

In addition to the $\alpha$-restrictions, a Granger causality (GC) test is applied on the contract pairs. The GC test tests whether lagged values of one variable contains information that explains the current value of another variable. An example of a GC test is whether lagged values of the play-money contract helps to explain the current value of the real-money contract, and vice versa. It is important to note that the presence of Granger causality does not imply causality (Enders, 2004), but only that past values of one variable affect the current value of another variable.

\begin{tabular}{lcccccc}
\hline & \multicolumn{2}{c}{ Overall Results } & & \multicolumn{3}{c}{ Market Specific Results } \\
\cline { 2 - 3 } \cline { 5 - 7 } Category & No. of Contracts & & Dem & Rep & Ind & Party \\
\hline Play-money g.c. real-money & 7 & & 2 & 3 & 2 & 0 \\
Real-money g.c. play-money & 4 & & 0 & 1 & 2 & 1 \\
Both markets g.c. each other & 6 & & 4 & 1 & 1 & 1 \\
No market g.c. the other & 13 & & 2 & 4 & 6 & 0 \\
\hline
\end{tabular}

Table 6: Granger causality tests (5\% level). (g.c.: Granger causes).

As with the $\alpha$-restriction tests, there are four possible outcomes: First, the play-money price Granger causes the real-money price, meaning that past prices of the play-money market contains information on the current value of the real-money market. Second, the real-money market price Granger causes the play-money price, which is equivalent to the reverse of the 
first possibility. Third, both markets may Granger cause each other, meaning that past prices of both markets help explain the current value of them. Last, there may be no variable Granger causing the other. The results available in Table 6, with full results available in Appendix B.5, indicate no clear pattern of the direction at which Granger causality occurs. Breaking up the results according to markets does not suggest any market specific patterns.

\subsection{Volume Effects}

The next step is to analyze whether the volume is related to presence of cointegration as well as if there is a difference between the real- and play-money markets with respect to volume. Accordingly, the following probit models are constructed:

$$
\begin{aligned}
& P(\text { Coint }=1 \mid \text { RealVolume })=C+\beta_{1} \text { RealVolume }+u \\
& P(\text { Coint }=1 \mid \text { PlayVolume })=C+\beta_{1} \text { PlayVolume }+u
\end{aligned}
$$

where Coint is a binary variable constructed from the cointegration results. It takes the value of one when there is cointegration and the value of zero when there is no cointegration. All contract pairs for which both variables at least once change prices are included in the analysis. This corresponds to the same set of pairs that were present in the unit root tests. The variables RealVolume and PlayVolume are summed over the time span of the different markets. The slope at the mean of the volume variable for the different models can be interpreted as the change in probability of cointegration from an increase of one unit in the traded volume on

\begin{tabular}{|c|c|c|c|c|c|c|}
\hline Variable & Coefficient & Std. Error & $t$-stat. & $p$-value & Slope (mean) & Sig. \\
\hline $\mathrm{C}$ & -1.5091 & 0.3691 & -4.089 & 0.0000 & & $* * *$ \\
\hline RealVolume & $2.0971 \mathrm{E}-05$ & $5.1591 \mathrm{E}-06$ & 4.065 & 0.0001 & $8.2318 \mathrm{E}-06$ & $* * *$ \\
\hline \multicolumn{3}{|c|}{ Number of cases 'correctly predicted' } & $40(83.3 \%)$ & & & \\
\hline \multicolumn{3}{|c|}{ McFadden's pseudo-R-squared } & 0.4261 & & & \\
\hline \multicolumn{7}{|c|}{ Model 2: Play volume, dependent variable: Coint } \\
\hline Variable & Coefficient & Std. Error & $t$-stat. & $p$-value & Slope (mean) & Sig. \\
\hline $\mathrm{C}$ & -1.3854 & 0.3433 & -4.035 & 0.0001 & & $* * *$ \\
\hline PlayVolume & $7.2662 \mathrm{E}-07$ & $1.7383 \mathrm{E}-07$ & 4.180 & 0.0000 & $2.7562 \mathrm{E}-07$ & $* * *$ \\
\hline \multicolumn{3}{|c|}{ Number of cases 'correctly predicted' } & $37(77.1 \%)$ & & & \\
\hline \multicolumn{3}{|c|}{ McFadden's pseudo-R-squared } & 0.3729 & & & \\
\hline
\end{tabular}
average.

Table 7: Probit models. (***: $1 \%$ level).

The results in Table 7 show clear evidence of volume positively affecting the probability of cointegration for both the real- and play-money market. The results are significant at the 1\%-level. Hence, volume has a clear positive effect on the markets being cointegrated. 


\subsection{A Closer Look at Period Two of the Republican Market}

In period two of the Republican market, the only uncertainty left is that of highly improbable events that would force John McCain to withdraw from the race. This fact makes it a logical step to look at the market price in relation to the payout rate upon expiry, since it can give a hint at what rate the market values the remaining risk. The market prices for the realand play-money market are presented in Figure 4. On May 24, the closing price of McCain was 95.0 in the real-money market. Buying a contract for 95.0 on May 24 and expecting to redeem 100 at expiry on September 1 when the Republican National Convention takes place, equals an annual interest rate of $20.82 \% .{ }^{10}$ Deducting a risk-free interest rate of $4.46 \%{ }^{11}$, it is obvious that the market is incorporating extraordinary levels of risk in the market, given the current situation, of being the only candidate left in the market.

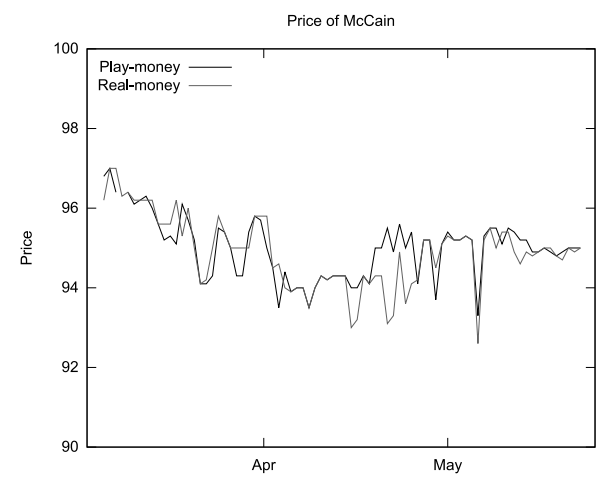

Figure 4: Price of McCain (March 6, 2008 - May 24, 2008).

The play-money market seems to exhibit the same behavior as the real-money market, which can also be observed in Figure 4. While it is plausible that the market interest rate for the real-money market reflects both the risk of McCain not being nominated and a return for giving up money now and collecting them upon contract expiry, it is unclear why the play-money market follows this behavior. In a play-money market there is no financial risk, only risk of losing reputation within the prediction market ranking system. Hence, the results suggest that the reputation risk is priced at a similar rate as the risk-free rate of return of the real-money market. Another interpretation is that one of the markets follows the other market, in other words, that there is evidence of Granger causality.

Results show that there is no evidence of Granger causality in any direction. Complete test results are available in Appendix B.6. This is a notable result, since it hints at the two markets operating independent of each other, yet at the same time pricing the contracts similarly.

\footnotetext{
${ }^{10}\left(\frac{\text { value upon expiry }}{\text { current value }}\right)^{\frac{\text { no. of days in a year }}{\text { no. of days until expiry }}}-1=\left(\frac{100}{95}\right)^{\frac{365}{99}}-1 \approx 0.2082$.

${ }^{11} 10$ year German Bundesbank market bond rate from July 11, 2008, retrieved from http://markets.ft.com/ markets/bonds.asp.
} 


\section{Conclusion}

Previous studies comparing real- and play-money prediction markets, surveyed in the theoretical framework, aimed at determining which of the two market types outperformed the other in terms of predictive accuracy. Such an approach is limited, since it does not take the time dimension into account and thereby ignores how the two market types interact when running in parallel. This study, therefore, aimed at exploring the time dynamics of the two market types.

The empirical study, based on four prediction markets of the U.S. presidential election in 2008, has revealed several notable results:

Result 1 The sum of the contract prices does not equal the payout rate.

The sum of the contract prices for each market seems to have stabilized at values above the payout rate for all four markets, in both the real- and play-money setting. This result indicates that there is reason to reject hypothesis one, that the sum of the contract prices should equal the payout rate. This result indicates the presence of persisting arbitrage in the markets.

Result 2 A majority of the markets are not cointegrated.

We have determined that cointegration is only present in $40 \%$ of the contract pairs exhibiting a price variance. ${ }^{12}$ Hence, the second hypothesis of cointegration between all markets cannot be supported.

Result 3 The real-money market cannot be determined to drive the play-money market.

This result implies that the real-money market cannot be determined to be superior in terms of information discovery because this would lead to a situation where the real-money market drives the play-money market. This is clearly not the case. It is rather market specific whether one market drives the other or vice versa.

Result 4 Volume has a significant and positive effect on the probability of cointegration.

Result four contradicts the argument of marginal traders making the markets efficient. While it does not necessarily reject this argument, it shows that higher volumes might attract marginal traders. Hence, as some authors have argued, that volume is largely irrelevant, cannot be supported by this result. Linking this conclusion to the information absorption power of the two markets, the result suggests that volume is more important than the presence of monetary incentives.

\footnotetext{
${ }^{12}$ Cointegration is evident in 18 of the 45 contract pairs that show price variation.
} 


\section{Discussion}

The results suggest that for contracts with a relatively high volume, both prediction markets run by play-money and real-money perform similarly. In connection with previous results, showing that biases diminish in real-money markets (Forsythe et al., 1999), it is possible to speculate that the force controlling the diminishing levels of biases, when moving from an individual to a market, lies in the information aggregation process rather than in the use of monetary incentives. If this is the case, its implications are far reaching, since it is, due to legal obstacles, difficult to operate a real-money market in many places around the world. It could also strengthen the interest in prediction markets of corporations wishing to improve business forecasting. Under such circumstances, it is not plausible to assume that an employee might want to participate if he has to risk parts of his own salary.

Another striking finding is that a large fraction of contracts are either not integrated of the same order, or when integrated of the same order, not cointegrated. This shows that the two markets operate in near isolation of each other. This means that the two markets react on, and absorb, different information, something that one would not expect given that one can access real-time quotes of both markets at any time. One can speculate that, given the relatively high volumes in both markets, one of the markets cannot attract marginal traders, and thus the market does not absorb critical information. Hence, one of the market types could be superior to the other. It is difficult to speculate on the issue of which market is the better one, partly because market participants can participate in both markets at the same time making it difficult to assume that the markets are independent of each other; and partly because the dataset does not contain information needed for such analysis. The study is based on daily observations of the market closing prices. Since trades are executed around the clock, this might not be the appropriate resolution to assess Granger causality or VECM $\alpha$-restrictions. To accurately assess whether or not one of the market drives or Granger causes the other, trade level data would be required. One can, however, through the probit analysis of volumes, conclude that higher volumes in both markets affect the probability of cointegration in the markets. In other words, this result shows that, with higher volumes, the markets start to react similarly on the same information. Hence, high volumes help both market types to better absorb information. Which of the markets performs better in low volume settings is however unclear.

Since there are no monetary incentives for participating in that market, one can speculate that the similarity arises through the social-comparison competition that is present in playmoney markets. It could also be that the play-money market mimics the behavior of the real-money market and would perform differently in isolation of a real-money market. While to answer this question is beyond the scope of this study, it is an important question to study. By implementing an experiment, the effect of running the markets in parallel could be 
determined. This is in particular important when determining the suitability of play-money markets as substitutes for real-money markets.

The presence of sustained arbitrage in the markets is also a notable finding. Although the existence of sustained overpricing might partly be caused by the existence of transaction costs, it shows that market participants are unable to take advantage of arbitrage. Hence, there seems to be a built in inefficiency in the market. In addition to the transaction costs, one can speculate that the number of contracts available in a market will negatively affect the pricing efficiency for the whole market. Essentially this is a design issue, because contracts cannot be traded at prices below 0.1 , the minimum tick size.

An additional result of the study, while not based on a hypothesis, is that the Republican market, in the time period where McCain was the implicit nominee, and thus run without the uncertainty of whom is to be elected, incorporates an interest rate of $20.82 \%$ on the contract of McCain. This means that the market is incorporating outside risks of McCain not being nominated as highly probable. Whether or not the McCain contract can be seen as a risk-free investment is unclear, but the market signals that this is not the case. While it is difficult to assess whether or not this is an appropriate interest rate, it is an arbitrage opportunity that does not seem to be taken advantage of. Would there be a healthy fraction of marginal traders, one would assume that the gap between the current contract interest rate and the risk-free bond rate would shrink. This does not seem to be the case. 


\section{References}

Berg, J. E., \& Rietz, T. A. (2003). Prediction markets as decision support systems. Information Systems Frontiers, 5(1), 79-93.

Chen, K.-Y., \& Plott, C. R. (2002). Information aggregation mechanisms: Concept, design and implementation for a sales forecasting problem. California Institute of Technology Social Science Working Paper 1131.

Cowgill, B., Wolfers, J., \& Zitzewitz, E. (2008). Using prediction markets to track information flows: Evidence from google. Mimeo.

Enders, W. (2004). Applied econometric time series. New York: John Wiley and Sons.

Forsythe, R., Nelson, F., Neumann, G., \& Wright, J. (1992). Anatomy of an experimental political stock market. American Economic Review, 82(5), 1142-1161.

Forsythe, R., Rietz, T. A., \& Ross, T. W. (1999). Wishes, expectations and actions: a survey on price formation in election stock markets. Journal of Economic Behavior and Organization, 39(1), 83-110.

Frey, B. S., \& Jegen, R. (2001). Motivation crowding theory. Journal of Economic Surveys, $15(5), 589-611$.

Hanson, R. (2006). Designing real terrorism futures. Public Choice, 128(1-2), 257-274.

Hanson, R. (2007). The policy analysis market: A thwarted experiment in the use of prediction markets for public policy. Innovations, 2(3), 73-88.

Hayek, F. A. (1945). The use of knowledge in society. American Economic Review, 35(4), 519-530.

Kiviat, B. (2004). The end of management? Time Magazine, July 12, 2004. Available from http://www.time.com/time/magazine/article/0,9171, 994658,00.html

Leigh, A., \& Wolfers, J. (2007). Prediction markets for business and public policy. The Melbourne Review, 3(1), 7-15.

Luckner, S., Weinhardt, C., \& Studer, R. (2006). Predictive power of two markets: A comparison of two sports forecasting exchanges. In T. Dreier, R. Studer, \& C. Weinhardt (Eds.), Information management and market engineering (p. 187-195). Karlsruhe: Universitätsverlag Karlsruhe.

Lütkepohl, H. (1999). Vector autoregressions. Mimeo.

Read, D. (2005). Monetary incentives, what are they good for? Journal of Economic Methodology, 12(2), 265-276.

Rosenbloom, E. S., \& Notz, W. (2006). Statistical tests of real-money versus play-money prediction markets. Electronic Markets, 16(1), 63-69.

Servan-Schreiber, E., Wolfers, J., Pennock, D. M., \& Galebach, B. (2004). Prediction markets: Does money matter? Electronic Markets, 14(3), 243-251.

Wolfers, J., \& Zitzewitz, E. (2004). Prediction markets. Journal of Economic Perspectives, $18(2), 107-126$. 


\section{A List of Contracts}

\begin{tabular}{|c|c|c|c|c|c|}
\hline \multirow[b]{2}{*}{ Market } & \multirow[b]{2}{*}{ Contract } & \multicolumn{2}{|c|}{ Real-money } & \multicolumn{2}{|c|}{ Play-money } \\
\hline & & Volume & Creation Date & Volume & Creation Date \\
\hline Democratic & Clinton & 371335 & $04 / 11 / 2004$ & 4078313 & $10 / 02 / 2007$ \\
\hline \multirow[t]{27}{*}{ Nominee } & Obama & 268018 & $05 / 11 / 2004$ & 3856907 & $10 / 02 / 2007$ \\
\hline & Gore & 121882 & $04 / 11 / 2004$ & 1546492 & $10 / 02 / 2007$ \\
\hline & Edwards & 61108 & $04 / 11 / 2004$ & 1242080 & $10 / 02 / 2007$ \\
\hline & Richardson & 21154 & $04 / 11 / 2004$ & 673860 & $10 / 02 / 2007$ \\
\hline & Biden & 17414 & $10 / 11 / 2004$ & 619251 & $11 / 02 / 2007$ \\
\hline & Field & 17122 & $15 / 09 / 2007$ & 290131 & $19 / 09 / 2007$ \\
\hline & Dodd & 4122 & $05 / 11 / 2004$ & 237353 & $15 / 02 / 2007$ \\
\hline & Kicinich & 3410 & $14 / 12 / 2006$ & 82904 & $10 / 06 / 2007$ \\
\hline & Warner, M & 1326 & $26 / 11 / 2004$ & 72902 & $13 / 02 / 2007$ \\
\hline & Kerry & 1302 & $04 / 11 / 2004$ & 72412 & $13 / 02 / 2007$ \\
\hline & Bayh & 1280 & $05 / 11 / 2004$ & 72601 & $11 / 02 / 2007$ \\
\hline & Dean & 1279 & $04 / 11 / 2004$ & 80900 & $14 / 02 / 2007$ \\
\hline & Easley & 1267 & $07 / 07 / 2005$ & 79089 & $18 / 10 / 2007$ \\
\hline & Feingold & 1227 & $21 / 12 / 2004$ & 80420 & $13 / 02 / 2007$ \\
\hline & Clark & 1223 & $04 / 11 / 2004$ & 91301 & $10 / 02 / 2007$ \\
\hline & Daschle & 1179 & $23 / 11 / 2005$ & 90799 & $14 / 02 / 2007$ \\
\hline & Schweitzer & 1179 & $07 / 07 / 2005$ & 80299 & $01 / 03 / 2007$ \\
\hline & Vilsack & 1179 & $09 / 11 / 2004$ & 75610 & $10 / 02 / 2007$ \\
\hline & Bredesen & 1169 & $17 / 02 / 2005$ & 80198 & $14 / 02 / 2007$ \\
\hline & Rendell & 1169 & $10 / 11 / 2004$ & 77999 & $27 / 02 / 2007$ \\
\hline & Lieberman & 1167 & $04 / 11 / 2004$ & 74999 & $04 / 05 / 2007$ \\
\hline & Powell & 1160 & $26 / 11 / 2004$ & 71899 & $11 / 02 / 2007$ \\
\hline & Leahy & 1158 & $05 / 11 / 2004$ & 77798 & $18 / 10 / 2007$ \\
\hline & Ford & 1156 & $10 / 11 / 2004$ & 73799 & $18 / 10 / 2007$ \\
\hline & Corzine & 1150 & $03 / 02 / 2005$ & 71798 & $14 / 02 / 2007$ \\
\hline & Blagojevich & 1095 & $11 / 04 / 2006$ & 76098 & $22 / 09 / 2007$ \\
\hline & Gravel & 1085 & $20 / 01 / 2007$ & 71485 & $12 / 02 / 2007$ \\
\hline Republican & Huckabee & 142695 & $15 / 06 / 2005$ & 2164289 & $10 / 02 / 2007$ \\
\hline \multirow[t]{32}{*}{ Nominee } & McCain & 111652 & $30 / 10 / 2004$ & 1568072 & $10 / 02 / 2007$ \\
\hline & Romney & 94928 & $30 / 10 / 2004$ & 2628140 & $10 / 02 / 2007$ \\
\hline & Giuliani & 84986 & $30 / 10 / 2004$ & 1381142 & $10 / 02 / 2007$ \\
\hline & Paul & 66126 & $20 / 01 / 2007$ & 2007708 & $10 / 02 / 2007$ \\
\hline & Thompson, F & 39033 & $10 / 03 / 2007$ & 844537 & $10 / 03 / 2007$ \\
\hline & Rice & 27267 & $30 / 10 / 2004$ & 331806 & $10 / 02 / 2007$ \\
\hline & Gingrich & 16351 & $30 / 01 / 2005$ & 264983 & $10 / 02 / 2007$ \\
\hline & Field & 11921 & $15 / 09 / 2007$ & 216595 & $19 / 09 / 2007$ \\
\hline & Bloomberg & 6018 & $17 / 11 / 2004$ & 22742 & $10 / 02 / 2007$ \\
\hline & Hunter & 4682 & $01 / 11 / 2006$ & 171378 & $10 / 02 / 2007$ \\
\hline & Dole & 3510 & $17 / 11 / 2004$ & 5079 & $17 / 03 / 2007$ \\
\hline & Bush, J & 861 & $30 / 10 / 2004$ & 12309 & $10 / 02 / 2007$ \\
\hline & Tancredo & 619 & $02 / 08 / 2006$ & 4159 & $10 / 02 / 2007$ \\
\hline & Hagel & 560 & $30 / 10 / 2004$ & 4265 & $10 / 02 / 2007$ \\
\hline & Barbour & 260 & $17 / 11 / 2004$ & 4461 & $07 / 04 / 2007$ \\
\hline & Cheney & 233 & $11 / 11 / 2004$ & 4419 & $10 / 02 / 2007$ \\
\hline & Allen & 111 & $30 / 10 / 2004$ & 127953 & $10 / 02 / 2007$ \\
\hline & Sanford & 100 & $16 / 03 / 2005$ & 58657 & $15 / 02 / 2007$ \\
\hline & Pataki & 21 & $30 / 10 / 2004$ & 5151 & $12 / 02 / 2007$ \\
\hline & Powell & 20 & $02 / 11 / 2004$ & 28892 & $10 / 02 / 2007$ \\
\hline & Brownback & 10 & $23 / 12 / 2004$ & 4939 & $10 / 02 / 2007$ \\
\hline & Frist & 10 & $30 / 10 / 2004$ & 909 & $22 / 02 / 2007$ \\
\hline & Owens & 10 & $30 / 10 / 2004$ & 1911 & $10 / 02 / 2007$ \\
\hline & Thompson, T & 10 & $30 / 10 / 2004$ & 2581 & $10 / 02 / 2007$ \\
\hline & Schwarzenegger & 5 & $05 / 11 / 2004$ & 2 & $14 / 02 / 2007$ \\
\hline & Franks & 0 & $16 / 12 / 2004$ & 4909 & $07 / 04 / 2007$ \\
\hline & Gilmore & 0 & $22 / 12 / 2006$ & 42 & $10 / 02 / 2007$ \\
\hline & Graham & 0 & $17 / 11 / 2004$ & 105 & $07 / 04 / 2007$ \\
\hline & Pawlenty & 0 & $19 / 02 / 2005$ & 11519 & $14 / 02 / 2007$ \\
\hline & Ridge & 0 & $30 / 10 / 2004$ & 2102 & $07 / 04 / 2007$ \\
\hline & Santorum & 0 & $17 / 11 / 2004$ & 11127 & $10 / 02 / 2007$ \\
\hline & Warner, J & 0 & $06 / 12 / 2006$ & 1857 & $07 / 04 / 2007$ \\
\hline
\end{tabular}




\begin{tabular}{|c|c|c|c|c|c|}
\hline \multirow[b]{2}{*}{ Market } & \multirow[b]{2}{*}{ Contract } & \multicolumn{2}{|c|}{ Real-money } & \multicolumn{2}{|c|}{ Play-money } \\
\hline & & Volume & Creation Date & Volume & Creation Date \\
\hline Individual & Clinton & 194871 & $14 / 07 / 2006$ & 3658370 & $10 / 02 / 2007$ \\
\hline \multirow[t]{17}{*}{ Winner } & McCain & 184826 & $14 / 07 / 2006$ & 4509718 & $10 / 02 / 2007$ \\
\hline & Obama & 141207 & $24 / 10 / 2006$ & 4233955 & $11 / 02 / 2007$ \\
\hline & Huckabee & 137970 & $29 / 08 / 2007$ & 4281330 & $28 / 08 / 2007$ \\
\hline & Romney & 125890 & $29 / 08 / 2006$ & 3436139 & $10 / 02 / 2007$ \\
\hline & Gore & 113290 & $30 / 08 / 2006$ & 2908596 & $15 / 02 / 2007$ \\
\hline & Giuliani & 104064 & $30 / 07 / 2006$ & 3039715 & $15 / 02 / 2007$ \\
\hline & Bloomberg & 100005 & $24 / 06 / 2007$ & 3009570 & $23 / 06 / 2007$ \\
\hline & Edwards & 99132 & $30 / 07 / 2006$ & 3225541 & $13 / 02 / 2007$ \\
\hline & Paul & 88354 & $28 / 08 / 2007$ & 3409533 & $28 / 08 / 2007$ \\
\hline & Thompson, F & 64564 & $04 / 04 / 2007$ & 2876025 & $04 / 04 / 2007$ \\
\hline & Field & 56319 & $29 / 08 / 2007$ & 2680380 & $30 / 08 / 2007$ \\
\hline & Biden & 10381 & $29 / 08 / 2007$ & 2259186 & $29 / 08 / 2007$ \\
\hline & Gingrich & 8996 & $29 / 08 / 2007$ & 316889 & $29 / 08 / 2007$ \\
\hline & Richardson & 8042 & $29 / 08 / 2007$ & 194473 & $28 / 08 / 2007$ \\
\hline & Dodd & 952 & $29 / 08 / 2007$ & 10627 & $11 / 09 / 2007$ \\
\hline & Allen & 24 & $29 / 08 / 2006$ & 22535 & $04 / 03 / 2007$ \\
\hline & Warner, M & 24 & $15 / 09 / 2006$ & 48353 & $11 / 05 / 2007$ \\
\hline Winning & Republican & 50337 & $20 / 10 / 2004$ & 960177 & $10 / 02 / 2007$ \\
\hline \multirow[t]{2}{*}{ Party } & Democratic & 44392 & $20 / 10 / 2004$ & 824830 & $10 / 02 / 2007$ \\
\hline & Field & 30104 & $10 / 11 / 2004$ & 542064 & $10 / 02 / 2007$ \\
\hline
\end{tabular}

Table 8: List of contracts of the four markets included in this study. Each market is sorted by real-money volume, in descending order.

\section{B Test Results}

Throughout the time series analyis, the number of lags are selected according to the Akaike Information Criterion (AIC).

In contrast to standard practice where stars represent the level at which an hypothesis is rejected, the stars for the Augmented Dickey-Fuller test represent not rejecting the null hypothesis of a unit root at a specified level, as seen in unit root tests on levels (Appendix B.1) and first differences (Appendix B.2).

In the cointegration tests (Appendix B.3) the null hypothesis is rejected when the test statistic (trace statistic) exceeds the critical value, Cointegration is present whenever the null hypothesis of "none" cointegrating relationships is rejected and the hypothesis of "at most 1 " is accepted.

In the table for the VECM $\alpha$-restrictions (Appendix B.4), the restrictions $\alpha_{p}=0$ and $\alpha_{r}=0$ (see equations (2) and (3)) are denoted by respectively $A(1,1)=0$ and $A(1,2)=0$, as they are identified by Eviews.

In the Granger causality tests (Appendix B.5), rejecting the null hypothesis indicates that Granger causality is present. 


\section{B.1 Unit Root Test Results: Levels}

\begin{tabular}{|c|c|c|c|c|c|c|c|c|c|}
\hline \multirow[b]{2}{*}{ Market } & \multirow[b]{2}{*}{ Contract } & \multirow[b]{2}{*}{ Real / Play } & \multirow{2}{*}{$\begin{array}{c}\text { Det. } \\
\text { Comp. }\end{array}$} & \multirow{2}{*}{$\begin{array}{l}\text { Lags } \\
\text { (AIC) }\end{array}$} & \multirow[b]{2}{*}{$t$-stat. } & \multicolumn{3}{|c|}{ Critical value } & \multirow[b]{2}{*}{ Sig. } \\
\hline & & & & & & $1 \%$ & $5 \%$ & $10 \%$ & \\
\hline Democratic & Biden & Play & i & 3 & -2.8497 & -3.4621 & -2.8754 & -2.5742 & $* *$ \\
\hline \multirow[t]{15}{*}{ Nomination } & & Real & $\mathrm{i}$ & 12 & -2.2471 & -3.4619 & -2.8753 & -2.5742 & $* * *$ \\
\hline & Clinton & Play & $\mathrm{i}, \mathrm{t}$ & 3 & -2.5021 & -4.0032 & -3.4318 & -3.1396 & $* * *$ \\
\hline & & Real & $\mathrm{i}, \mathrm{t}$ & 0 & -2.9154 & -4.0005 & -3.4305 & -3.1388 & $* * *$ \\
\hline & Dodd & Play & $\mathrm{i}, \mathrm{t}$ & 11 & -1.8504 & -4.0093 & -3.4347 & -3.1413 & $* * *$ \\
\hline & & Real & $\mathrm{i}, \mathrm{t}$ & 14 & -2.5219 & -4.0034 & -3.4319 & -3.1397 & $* * *$ \\
\hline & Edwards & Play & $\mathrm{i}$ & 6 & 0.7670 & -3.4636 & -2.8760 & -2.5746 & $* * *$ \\
\hline & & Real & $\mathrm{i}$ & 6 & -1.0617 & -3.4610 & -2.8749 & -2.5740 & $* * *$ \\
\hline & Field & Play & $\mathrm{i}$ & 9 & -1.4975 & -3.4652 & -2.8768 & -2.5750 & $* * *$ \\
\hline & & Real & $\mathrm{i}$ & 7 & -1.6023 & -3.4612 & -2.8750 & -2.5740 & $* * *$ \\
\hline & Gore & Play & i & 1 & -1.6062 & -3.4612 & -2.8750 & -2.5740 & $* * *$ \\
\hline & & Real & $\mathrm{i}$ & 1 & -1.8117 & -3.4603 & -2.8746 & -2.5738 & $* * *$ \\
\hline & Obama & Play & $\mathrm{i}, \mathrm{t}$ & 3 & -2.5375 & -4.0032 & -3.4318 & -3.1396 & $* * *$ \\
\hline & & Real & $\mathrm{i}, \mathrm{t}$ & 0 & -2.8935 & -4.0005 & -3.4305 & -3.1388 & $* * *$ \\
\hline & Richardson & Play & $\mathrm{i}, \mathrm{t}$ & 10 & -1.4307 & -4.0084 & -3.4343 & -3.1411 & $* * *$ \\
\hline & & Real & $\mathrm{i}, \mathrm{t}$ & 11 & -1.3609 & -4.0028 & -3.4316 & -3.1395 & $* * *$ \\
\hline \multirow{20}{*}{$\begin{array}{l}\text { Republican } \\
\text { (Period 1) }\end{array}$} & Bloomberg & Play & $\mathrm{i}$ & 0 & -10.7409 & -3.4699 & -2.8788 & -2.5761 & \\
\hline & & Real & $\mathrm{i}$ & 0 & -5.6682 & -3.4695 & -2.8786 & -2.5760 & \\
\hline & Gingrich & Play & $\mathrm{i}$ & 0 & -4.7227 & -3.4699 & -2.8788 & -2.5761 & \\
\hline & & Real & $\mathrm{i}$ & 2 & -3.4028 & -3.4699 & -2.8788 & -2.5761 & $*$ \\
\hline & Giuliani & Play & $\mathrm{i}, \mathrm{t}$ & 9 & -2.3471 & -4.0213 & -3.4405 & -3.1447 & $* * *$ \\
\hline & & Real & $\mathrm{i}, \mathrm{t}$ & 0 & -1.9240 & -4.0136 & -3.4368 & -3.1425 & $* * *$ \\
\hline & Huckabee & Play & $\mathrm{i}$ & 0 & -3.3907 & -3.4699 & -2.8788 & -2.5761 & $*$ \\
\hline & & Real & $\mathrm{i}$ & 0 & -1.2557 & -3.4695 & -2.8786 & -2.5760 & $* * *$ \\
\hline & Hunter & Play & $\mathrm{i}$ & 12 & -2.7458 & -3.4768 & -2.8818 & -2.5777 & $* *$ \\
\hline & & Real & $\mathrm{i}$ & 5 & -3.9629 & -3.4707 & -2.8792 & -2.5762 & \\
\hline & McCain & Play & $\mathrm{i}$ & 10 & -0.2878 & -3.4755 & -2.8813 & -2.5774 & $* * *$ \\
\hline & & Real & $\mathrm{i}$ & 10 & -0.1408 & -3.4720 & -2.8797 & -2.5765 & $* * *$ \\
\hline & Paul & Play & $\mathrm{i}$ & 2 & -0.5779 & -3.4709 & -2.8793 & -2.5763 & $* * *$ \\
\hline & & Real & $\mathrm{i}$ & 4 & -0.7353 & -3.4704 & -2.8790 & -2.5762 & $* * *$ \\
\hline & Rice & Play & $\mathrm{i}$ & 5 & -1.6657 & -3.4725 & -2.8800 & -2.5767 & $* * *$ \\
\hline & & Real & $\mathrm{i}$ & 4 & -1.5193 & -3.4704 & -2.8790 & -2.5762 & $* * *$ \\
\hline & Romney & Play & $\mathrm{i}$ & 5 & -1.0977 & -3.4725 & -2.8800 & -2.5767 & $* * *$ \\
\hline & & Real & $\mathrm{i}$ & 8 & -1.3355 & -3.4715 & -2.8795 & -2.5764 & $* * *$ \\
\hline & Thompson, F & Play & $\mathrm{i}, \mathrm{t}$ & 1 & -2.3948 & -4.0150 & -3.4375 & -3.1429 & $* * *$ \\
\hline & & Real & $\mathrm{i}, \mathrm{t}$ & 4 & -1.7567 & -4.0150 & -3.4375 & -3.1429 & $* * *$ \\
\hline \multirow{18}{*}{$\begin{array}{l}\text { Republican } \\
\text { (Period 2) }\end{array}$} & Field & Play & $\mathrm{i}$ & 7 & -2.1761 & -3.5256 & -2.9030 & -2.5889 & $* * *$ \\
\hline & & Real & $\mathrm{i}$ & 1 & -3.7367 & -3.5144 & -2.8981 & -2.5864 & \\
\hline & Gingrich & Play & $\mathrm{i}$ & 0 & -2.1176 & -3.5167 & -2.8991 & -2.5869 & $* * *$ \\
\hline & & Real & $\mathrm{i}$ & 1 & -4.4818 & -3.5144 & -2.8981 & -2.5864 & \\
\hline & Giuliani & Play & $\mathrm{i}$ & 2 & -0.8422 & -3.5191 & -2.9001 & -2.5874 & $* * *$ \\
\hline & & Real & $\mathrm{i}$ & 4 & 0.8412 & -3.5144 & -2.8981 & -2.5864 & $* * *$ \\
\hline & Huckabee & Play & $\mathrm{i}$ & 0 & -3.5533 & -3.5167 & -2.8991 & -2.5869 & \\
\hline & & Real & $\mathrm{i}$ & 1 & -3.2520 & -3.5144 & -2.8981 & -2.5864 & $*$ \\
\hline & McCain & Play & $\mathrm{i}$ & 0 & -3.9727 & -3.5167 & -2.8991 & -2.5869 & \\
\hline & & Real & $\mathrm{i}$ & 2 & -2.4974 & -3.5144 & -2.8981 & -2.5864 & $* * *$ \\
\hline & Paul & Play & $\mathrm{i}$ & 0 & -1.4738 & -3.5167 & -2.8991 & -2.5869 & $* * *$ \\
\hline & & Real & $\mathrm{i}$ & 0 & -8.6469 & -3.5144 & -2.8981 & -2.5864 & \\
\hline & Rice & Play & $\mathrm{i}$ & 7 & -1.7939 & -3.5256 & -2.9030 & -2.5889 & $* * *$ \\
\hline & & Real & $\mathrm{i}$ & 0 & -1.6528 & -3.5144 & -2.8981 & -2.5864 & $* * *$ \\
\hline & Romney & Play & $\mathrm{i}$ & 0 & -2.1137 & -3.5167 & -2.8991 & -2.5869 & $* * *$ \\
\hline & & Real & $\mathrm{i}$ & 7 & -2.3044 & -3.5144 & -2.8981 & -2.5864 & $* * *$ \\
\hline & Thompson, F & Play & $\mathrm{i}$ & 0 & -2.5175 & -3.5167 & -2.8991 & -2.5869 & $* * *$ \\
\hline & & Real & $\mathrm{i}$ & 3 & -3.8849 & -3.5144 & -2.8981 & -2.5864 & \\
\hline
\end{tabular}




\begin{tabular}{|c|c|c|c|c|c|c|c|c|c|}
\hline \multirow[b]{2}{*}{ Market } & \multirow[b]{2}{*}{ Contract } & \multirow[b]{2}{*}{ Real / Play } & \multirow{2}{*}{$\begin{array}{c}\text { Det. } \\
\text { Comp. }\end{array}$} & \multirow{2}{*}{$\begin{array}{l}\text { Lags } \\
\text { (AIC) }\end{array}$} & \multirow[b]{2}{*}{ t-stat. } & \multicolumn{3}{|c|}{ Critical value } & \multirow[t]{2}{*}{ Sig. } \\
\hline & & & & & & $1 \%$ & $5 \%$ & $10 \%$ & \\
\hline Individual & Biden & Play & $\mathrm{i}$ & 13 & -1.2737 & -3.4610 & -2.8749 & -2.5740 & $* * *$ \\
\hline \multirow[t]{29}{*}{ Winner } & & Real & $\mathrm{i}$ & 8 & -3.1726 & -3.4566 & -2.8730 & -2.5730 & * \\
\hline & Bloomberg & Play & $\mathrm{i}$ & 2 & -3.5518 & -3.4568 & -2.8730 & -2.5730 & \\
\hline & & Real & $\mathrm{i}$ & 3 & -2.2038 & -3.4561 & -2.8728 & -2.5728 & $* * *$ \\
\hline & Clinton & Play & $\mathrm{i}, \mathrm{t}$ & 2 & -3.0084 & -3.9958 & -3.4282 & -3.1375 & $* * *$ \\
\hline & & Real & $\mathrm{i}, \mathrm{t}$ & 0 & -2.8566 & -3.9943 & -3.4275 & -3.1371 & $* * *$ \\
\hline & Edwards & Play & $\mathrm{i}, \mathrm{t}$ & 13 & 0.5213 & -4.0017 & -3.4311 & -3.1392 & $* * *$ \\
\hline & & Real & $\mathrm{i}, \mathrm{t}$ & 4 & -1.8671 & -3.9949 & -3.4278 & -3.1372 & $* * *$ \\
\hline & Field & Play & $\mathrm{i}$ & 13 & -1.6557 & -3.4610 & -2.8749 & -2.5740 & $* * *$ \\
\hline & & Real & $\mathrm{i}$ & 6 & -0.0365 & -3.4564 & -2.8729 & -2.5729 & $* * *$ \\
\hline & Gingrich & Play & $\mathrm{i}$ & 14 & -2.9311 & -3.4615 & -2.8751 & -2.5741 & $*$ \\
\hline & & Real & $\mathrm{i}$ & 14 & -3.9898 & -3.4573 & -2.8733 & -2.5731 & \\
\hline & Giuliani & Play & $\mathrm{i}$ & 14 & -0.8253 & -3.4615 & -2.8751 & -2.5741 & $* * *$ \\
\hline & & Real & $\mathrm{i}$ & 0 & -0.7784 & -3.4558 & -2.8726 & -2.5728 & $* * *$ \\
\hline & Gore & Play & $\mathrm{i}$ & 1 & -1.7804 & -3.4565 & -2.8730 & -2.5729 & $* * *$ \\
\hline & & Real & $\mathrm{i}$ & 2 & -1.8751 & -3.4560 & -2.8727 & -2.5728 & $* * *$ \\
\hline & Huckabee & Play & $\mathrm{i}$ & 6 & -1.1141 & -3.4582 & -2.8737 & -2.5733 & $* * *$ \\
\hline & & Real & $\mathrm{i}$ & 0 & -1.5535 & -3.4558 & -2.8726 & -2.5728 & $* * *$ \\
\hline & McCain & Play & $\mathrm{i}, \mathrm{t}$ & 10 & -1.5411 & -3.9999 & -3.4302 & -3.1387 & $* * *$ \\
\hline & & Real & $\mathrm{i}, \mathrm{t}$ & 4 & -1.2313 & -3.9949 & -3.4278 & -3.1372 & $* * *$ \\
\hline & Obama & Play & $\mathrm{i}, \mathrm{t}$ & 3 & -2.7586 & -3.9963 & -3.4284 & -3.1376 & $* * *$ \\
\hline & & Real & $\mathrm{i}, \mathrm{t}$ & 0 & -2.4183 & -3.9943 & -3.4275 & -3.1371 & $* * *$ \\
\hline & Paul & Play & $\mathrm{i}$ & 8 & -0.2915 & -3.4590 & -2.8740 & -2.5735 & $* * *$ \\
\hline & & Real & $\mathrm{i}$ & 7 & -1.1426 & -3.4565 & -2.8730 & -2.5729 & $* * *$ \\
\hline & Richardson & Play & $\mathrm{i}$ & 14 & -1.3737 & -3.4615 & -2.8751 & -2.5741 & $* * *$ \\
\hline & & Real & $\mathrm{i}$ & 5 & -4.9567 & -3.4563 & -2.8729 & -2.5729 & \\
\hline & Romney & Play & $\mathrm{i}, \mathrm{t}$ & 3 & -2.5130 & -3.9963 & -3.4284 & -3.1376 & $* * *$ \\
\hline & & Real & $\mathrm{i}, \mathrm{t}$ & 0 & -2.5246 & -3.9943 & -3.4275 & -3.1371 & $* * *$ \\
\hline & Thompson, F & Play & $\mathrm{i}, \mathrm{t}$ & 10 & -2.3775 & -3.9999 & -3.4302 & -3.1387 & $* * *$ \\
\hline & & Real & $\mathrm{i}, \mathrm{t}$ & 11 & -3.3818 & -3.9960 & -3.4283 & -3.1375 & $* *$ \\
\hline \multirow{6}{*}{$\begin{array}{l}\text { Party } \\
\text { Winner }\end{array}$} & Democratic & Play & $\mathrm{i}$ & 8 & -1.4136 & -3.4450 & -2.8679 & -2.5702 & $* * *$ \\
\hline & & Real & $\mathrm{i}$ & 3 & -1.2299 & -3.4442 & -2.8675 & -2.5700 & $* * *$ \\
\hline & Field & Play & $\mathrm{i}$ & 14 & -1.4690 & -3.4456 & -2.8682 & -2.5704 & $* * *$ \\
\hline & & Real & $\mathrm{i}$ & 1 & -2.1141 & -3.4441 & -2.8675 & -2.5700 & $* * *$ \\
\hline & Republican & Play & $\mathrm{i}$ & 6 & -3.5537 & -3.4448 & -2.8678 & -2.5702 & \\
\hline & & Real & $\mathrm{i}$ & 1 & -2.1308 & -3.4441 & -2.8675 & -2.5700 & $* * *$ \\
\hline
\end{tabular}

Table 9: Augmented Dickey-Fuller test on levels. (Det. Comp.: Deterministic Components; i: intercept; t: trend; *: $1 \%$ level; **: $5 \%$ level; ***: $10 \%$ level). 


\section{B.2 Unit Root Test Results: First Differences}

\begin{tabular}{|c|c|c|c|c|c|c|c|c|c|}
\hline \multirow[b]{2}{*}{ Market } & \multirow[b]{2}{*}{ Contract } & \multirow[b]{2}{*}{ Real / Play } & \multirow{2}{*}{$\begin{array}{c}\text { Det. } \\
\text { Comp. }\end{array}$} & \multirow{2}{*}{$\begin{array}{l}\text { Lags } \\
\text { (AIC) }\end{array}$} & \multirow[b]{2}{*}{$t$-stat. } & \multicolumn{3}{|c|}{ Critical value } & \multirow[t]{2}{*}{ Sig } \\
\hline & & & & & & $1 \%$ & $5 \%$ & $10 \%$ & \\
\hline Democratic & Biden & Play & & 2 & -13.1841 & -2.5762 & -1.9424 & -1.6157 & \\
\hline \multirow[t]{15}{*}{ Nomination } & & Real & & 11 & -7.5539 & -2.5762 & -1.9424 & -1.6157 & \\
\hline & Clinton & Play & $\mathrm{i}$ & 2 & -8.4755 & -3.4621 & -2.8754 & -2.5742 & \\
\hline & & Real & $\mathrm{i}$ & 0 & -15.8284 & -3.4603 & -2.8746 & -2.5738 & \\
\hline & Dodd & Play & $\mathrm{i}$ & 8 & -8.3686 & -3.4652 & -2.8768 & -2.5750 & \\
\hline & & Real & $\mathrm{i}$ & 13 & -3.9147 & -3.4623 & -2.8755 & -2.5743 & \\
\hline & Edwards & Play & & 5 & -8.4166 & -2.5768 & -1.9424 & -1.6156 & \\
\hline & & Real & & 5 & -5.8678 & -2.5759 & -1.9423 & -1.6157 & \\
\hline & Field & Play & & 0 & -15.9123 & -2.5759 & -1.9423 & -1.6157 & \\
\hline & & Real & & 6 & -6.1032 & -2.5759 & -1.9423 & -1.6157 & \\
\hline & Gore & Play & & 1 & -11.4713 & -2.5761 & -1.9424 & -1.6157 & \\
\hline & & Real & & 0 & -16.5043 & -2.5756 & -1.9423 & -1.6157 & \\
\hline & Obama & Play & $\mathrm{i}$ & 2 & -7.1049 & -3.4621 & -2.8754 & -2.5742 & \\
\hline & & Real & $\mathrm{i}$ & 0 & -15.5597 & -3.4603 & -2.8746 & -2.5738 & \\
\hline & Richardson & Play & $\mathrm{i}$ & 9 & -5.9330 & -3.4658 & -2.8770 & -2.5751 & \\
\hline & & Real & $\mathrm{i}$ & 10 & -6.7024 & -3.4618 & -2.8753 & -2.5742 & \\
\hline \multirow{20}{*}{$\begin{array}{l}\text { Republican } \\
\text { (Period 1) }\end{array}$} & Bloomberg & Play & & 3 & -7.4811 & -2.5797 & -1.9429 & -1.6154 & \\
\hline & & Real & & 3 & -10.1977 & -2.5791 & -1.9428 & -1.6154 & \\
\hline & Gingrich & Play & & 11 & -5.7074 & -2.5813 & -1.9431 & -1.6152 & \\
\hline & & Real & & 1 & -9.6305 & -2.5790 & -1.9428 & -1.6154 & \\
\hline & Giuliani & Play & $\mathrm{i}$ & 8 & -4.3406 & -3.4749 & -2.8810 & -2.5772 & \\
\hline & & Real & $\mathrm{i}$ & 0 & -11.8592 & -3.4697 & -2.8787 & -2.5760 & \\
\hline & Huckabee & Play & & 0 & -19.7689 & -2.5791 & -1.9428 & -1.6154 & \\
\hline & & Real & & 0 & -12.8123 & -2.5789 & -1.9427 & -1.6154 & \\
\hline & Hunter & Play & & 11 & -5.3823 & -2.5813 & -1.9431 & -1.6152 & \\
\hline & & Real & & 7 & -6.8619 & -2.5795 & -1.9428 & -1.6154 & \\
\hline & McCain & Play & & 9 & -1.6206 & -2.5809 & -1.9430 & -1.6153 & $* *$ \\
\hline & & Real & & 9 & -2.1046 & -2.5797 & -1.9429 & -1.6154 & $*$ \\
\hline & Paul & Play & & 1 & -11.9585 & -2.5793 & -1.9428 & -1.6154 & \\
\hline & & Real & & 3 & -6.6364 & -2.5791 & -1.9428 & -1.6154 & \\
\hline & Rice & Play & & 4 & -8.5895 & -2.5799 & -1.9429 & -1.6154 & \\
\hline & & Real & & 3 & -9.0817 & -2.5791 & -1.9428 & -1.6154 & \\
\hline & Romney & Play & & 4 & -4.8697 & -2.5799 & -1.9429 & -1.6154 & \\
\hline & & Real & & 6 & -4.4239 & -2.5794 & -1.9428 & -1.6154 & \\
\hline & Thompson, F & Play & $\mathrm{i}$ & 9 & -2.9091 & -3.4755 & -2.8813 & -2.5774 & $*$ \\
\hline & & Real & $\mathrm{i}$ & 1 & -7.6852 & -3.4699 & -2.8788 & -2.5761 & \\
\hline \multirow{18}{*}{$\begin{array}{l}\text { Republican } \\
\text { (Period 2) }\end{array}$} & Field & Play & & 6 & -4.9815 & -2.5979 & -1.9455 & -1.6138 & \\
\hline & & Real & & 1 & -9.6988 & -2.5942 & -1.9449 & -1.6141 & \\
\hline & Gingrich & Play & & 1 & -7.8528 & -2.5957 & -1.9451 & -1.6140 & \\
\hline & & Real & & 11 & -5.7610 & -2.5942 & -1.9449 & -1.6141 & \\
\hline & Giuliani & Play & & 1 & -9.1425 & -2.5957 & -1.9451 & -1.6140 & \\
\hline & & Real & & 3 & -7.0020 & -2.5942 & -1.9449 & -1.6141 & \\
\hline & Huckabee & Play & & 0 & -10.5780 & -2.5953 & -1.9451 & -1.6140 & \\
\hline & & Real & & 0 & -7.6197 & -2.5942 & -1.9449 & -1.6141 & \\
\hline & McCain & Play & & 6 & -2.8986 & -2.5979 & -1.9455 & -1.6138 & \\
\hline & & Real & & 1 & -10.2231 & -2.5942 & -1.9449 & -1.6141 & \\
\hline & Paul & Play & & 0 & -7.8602 & -2.5953 & -1.9451 & -1.6140 & \\
\hline & & Real & & 3 & -7.5728 & -2.5942 & -1.9449 & -1.6141 & \\
\hline & Rice & Play & & 6 & -4.8866 & -2.5979 & -1.9455 & -1.6138 & \\
\hline & & Real & & 0 & -9.6539 & -2.5942 & -1.9449 & -1.6141 & \\
\hline & Romney & Play & & 1 & -8.1959 & -2.5957 & -1.9451 & -1.6140 & \\
\hline & & Real & & 0 & -9.6206 & -2.5942 & -1.9449 & -1.6141 & \\
\hline & Thompson, F & Play & & 1 & -6.7772 & -2.5957 & -1.9451 & -1.6140 & \\
\hline & & Real & & 2 & -7.8486 & -2.5942 & -1.9449 & -1.6141 & \\
\hline
\end{tabular}




\begin{tabular}{|c|c|c|c|c|c|c|c|c|c|}
\hline \multirow[b]{2}{*}{ Market } & \multirow[b]{2}{*}{ Contract } & \multirow[b]{2}{*}{ Real / Play } & \multirow{2}{*}{$\begin{array}{c}\text { Det. } \\
\text { Comp. }\end{array}$} & \multirow{2}{*}{$\begin{array}{l}\text { Lags } \\
\text { (AIC) }\end{array}$} & \multirow[b]{2}{*}{$t$-stat. } & \multicolumn{3}{|c|}{ Critical value } & \multirow[t]{2}{*}{ Sig. } \\
\hline & & & & & & $1 \%$ & $5 \%$ & $10 \%$ & \\
\hline Individual & Biden & Play & & 12 & -7.9081 & -2.5759 & -1.9423 & -1.6157 & \\
\hline \multirow[t]{29}{*}{ Winner } & & Real & & 7 & -8.7843 & -2.5743 & -1.9421 & -1.6158 & \\
\hline & Bloomberg & Play & & 9 & -8.0722 & -2.5754 & -1.9423 & -1.6157 & \\
\hline & & Real & & 3 & -11.0732 & -2.5742 & -1.9421 & -1.6159 & \\
\hline & Clinton & Play & $\mathrm{i}$ & 1 & -11.6162 & -3.4568 & -2.8731 & -2.5730 & \\
\hline & & Real & $\mathrm{i}$ & 0 & -17.2758 & -3.4559 & -2.8727 & -2.5728 & \\
\hline & Edwards & Play & $\mathrm{i}$ & 12 & -7.0930 & -3.4610 & -2.8749 & -2.5740 & \\
\hline & & Real & $\mathrm{i}$ & 3 & -11.6091 & -3.4562 & -2.8728 & -2.5729 & \\
\hline & Field & Play & & 13 & -7.9212 & -2.5760 & -1.9423 & -1.6157 & \\
\hline & & Real & & 5 & -9.3067 & -2.5742 & -1.9421 & -1.6159 & \\
\hline & Gingrich & Play & & 8 & -10.3813 & -2.5753 & -1.9422 & -1.6158 & \\
\hline & & Real & & 15 & -5.7760 & -2.5746 & -1.9422 & -1.6158 & \\
\hline & Giuliani & Play & & 13 & -2.6426 & -2.5760 & -1.9423 & -1.6157 & \\
\hline & & Real & & 0 & -15.1797 & -2.5741 & -1.9421 & -1.6159 & \\
\hline & Gore & Play & & 0 & -21.0636 & -2.5743 & -1.9421 & -1.6158 & \\
\hline & & Real & & 1 & -14.3700 & -2.5741 & -1.9421 & -1.6159 & \\
\hline & Huckabee & Play & & 5 & -9.5821 & -2.5749 & -1.9422 & -1.6158 & \\
\hline & & Real & & 5 & -9.5821 & -2.5749 & -1.9422 & -1.6158 & \\
\hline & McCain & Play & $\mathrm{i}$ & 9 & -4.3474 & -3.4598 & -2.8744 & -2.5737 & \\
\hline & & Real & $\mathrm{i}$ & 3 & -8.4339 & -3.4562 & -2.8728 & -2.5729 & \\
\hline & Obama & Play & $\mathrm{i}$ & 2 & -7.3049 & -3.4572 & -2.8732 & -2.5731 & \\
\hline & & Real & $\mathrm{i}$ & 4 & -7.4384 & -3.4563 & -2.8729 & -2.5729 & \\
\hline & Paul & Play & & 7 & -7.7693 & -2.5751 & -1.9422 & -1.6158 & \\
\hline & & Real & & 6 & -5.5429 & -2.5743 & -1.9421 & -1.6158 & \\
\hline & Richardson & Play & & 13 & -8.6629 & -2.5760 & -1.9423 & -1.6157 & \\
\hline & & Real & & 14 & -7.6348 & -2.5746 & -1.9421 & -1.6158 & \\
\hline & Romney & Play & $\mathrm{i}$ & 2 & -9.5238 & -3.4572 & -2.8732 & -2.5731 & \\
\hline & & Real & $\mathrm{i}$ & 0 & -16.6465 & -3.4559 & -2.8727 & -2.5728 & \\
\hline & Thompson, F & Play & $\mathrm{i}$ & 1 & -15.3444 & -3.4568 & -2.8731 & -2.5730 & \\
\hline & & Real & $\mathrm{i}$ & 10 & -3.1202 & -3.4570 & -2.8731 & -2.5730 & $*$ \\
\hline Party & Democratic & Play & & 7 & -12.1750 & -2.5702 & -1.9415 & -1.6162 & \\
\hline \multirow[t]{5}{*}{ Winner } & & Real & & 2 & -15.6615 & -2.5699 & -1.9415 & -1.6162 & \\
\hline & Field & Play & & 13 & -6.6728 & -2.5704 & -1.9416 & -1.6162 & \\
\hline & & Real & & 3 & -12.8937 & -2.5699 & -1.9415 & -1.6162 & \\
\hline & Republican & Play & & 7 & -11.9395 & -2.5702 & -1.9415 & -1.6162 & \\
\hline & & Real & & 2 & -14.8161 & -2.5699 & -1.9415 & -1.6162 & \\
\hline
\end{tabular}

Table 10: Augmented Dickey-Fuller test on first differences. (Det. Comp.: Deterministic Components; i: intercept; t: trend; *: $1 \%$ level; **: $5 \%$ level; ***: $10 \%$ level). 


\section{B.3 Cointegration Test Results}

\begin{tabular}{|c|c|c|c|c|c|c|}
\hline \multirow{17}{*}{$\begin{array}{l}\text { Market } \\
\text { Democratic } \\
\text { Nomination }\end{array}$} & \multicolumn{3}{|c|}{ Lags } & \multicolumn{2}{|r|}{ Crit. val. } & $p$-value \\
\hline & \multirow{2}{*}{ Biden } & \multirow[t]{2}{*}{8} & None & 18.7818 & 25.8721 & 0.2938 \\
\hline & & & At most 1 & 5.0419 & 12.5180 & 0.5904 \\
\hline & \multirow[t]{2}{*}{ Clinton } & \multirow[t]{2}{*}{1} & None & 100.6215 & 25.8721 & 0.0000 \\
\hline & & & At most 1 & 9.8623 & 12.5180 & 0.1335 \\
\hline & \multirow[t]{2}{*}{ Dodd } & \multirow[t]{2}{*}{5} & None & 35.2054 & 25.8721 & 0.0026 \\
\hline & & & At most 1 & 4.4825 & 12.5180 & 0.6716 \\
\hline & \multirow[t]{2}{*}{ Edwards } & \multirow[t]{2}{*}{6} & None & 17.2190 & 25.8721 & 0.3988 \\
\hline & & & At most 1 & 1.1648 & 12.5180 & 0.9976 \\
\hline & \multirow[t]{2}{*}{ Field } & \multirow[t]{2}{*}{8} & None & 21.2049 & 25.8721 & 0.1710 \\
\hline & & & At most 1 & 2.8815 & 12.5180 & 0.8903 \\
\hline & \multirow[t]{2}{*}{ Gore } & \multirow[t]{2}{*}{2} & None & 51.5559 & 25.8721 & 0.0000 \\
\hline & & & At most 1 & 4.1141 & 12.5180 & 0.7255 \\
\hline & \multirow[t]{2}{*}{ Obama } & 5 & None & 37.2141 & 25.8721 & 0.0013 \\
\hline & & & At most 1 & 7.1952 & 12.5180 & 0.3246 \\
\hline & Richardson & 7 & None & 16.0575 & 25.8721 & 0.4880 \\
\hline & & & At most 1 & 6.3938 & 12.5180 & 0.4120 \\
\hline Republican & Giuliani & 1 & None & 84.5643 & 25.8721 & 0.0000 \\
\hline (Period 1) & & & At most 1 & 10.8147 & 12.5180 & 0.0947 \\
\hline & Paul & 1 & None & 67.6616 & 25.8721 & 0.0000 \\
\hline & & & At most 1 & 6.6017 & 12.5180 & 0.3879 \\
\hline & Rice & 3 & None & 40.5192 & 25.8721 & 0.0004 \\
\hline & & & At most 1 & 9.1090 & 12.5180 & 0.1737 \\
\hline & Romney & 6 & None & 23.9893 & 25.8721 & 0.0842 \\
\hline & & & At most 1 & 7.0631 & 12.5180 & 0.3380 \\
\hline & Thompson, F & 1 & None & 105.6917 & 25.8721 & 0.0000 \\
\hline & & & At most 1 & 14.6820 & 12.5180 & 0.0214 \\
\hline Republican & Giuliani & 5 & None & 20.6812 & 25.8721 & 0.1933 \\
\hline (Period 2) & & & At most 1 & 5.8645 & 12.5180 & 0.4777 \\
\hline & Rice & 7 & None & 19.7468 & 25.8721 & 0.2390 \\
\hline & & & At most 1 & 8.6499 & 12.5180 & 0.2031 \\
\hline & Romney & 2 & None & 24.4356 & 25.8721 & 0.0747 \\
\hline & & & At most 1 & 5.6736 & 12.5180 & 0.5028 \\
\hline Individual & Clinton & 1 & None & 100.1151 & 25.8721 & 0.0000 \\
\hline Winner & & & At most 1 & 8.5705 & 12.5180 & 0.2085 \\
\hline & Edwards & 4 & None & 36.2401 & 25.8721 & 0.0018 \\
\hline & & & At most 1 & 1.3661 & 12.5180 & 0.9943 \\
\hline & Field & 3 & None & 37.2315 & 25.8721 & 0.0013 \\
\hline & & & At most 1 & 5.0404 & 12.5180 & 0.5906 \\
\hline & Giuliani & 7 & None & 29.9583 & 25.8721 & 0.0146 \\
\hline & & & At most 1 & 1.9539 & 12.5180 & 0.9714 \\
\hline & Gore & 6 & None & 27.5805 & 25.8721 & 0.0304 \\
\hline & & & At most 1 & 4.5664 & 12.5180 & 0.6594 \\
\hline & Huckabee & 6 & None & 63.0859 & 25.8721 & 0.0000 \\
\hline & & & At most 1 & 3.5160 & 12.5180 & 0.8104 \\
\hline & McCain & 5 & None & 35.3409 & 25.8721 & 0.0025 \\
\hline & & & At most 1 & 2.1680 & 12.5180 & 0.9574 \\
\hline & Obama & 4 & None & 53.1762 & 25.8721 & 0.0000 \\
\hline & & & At most 1 & 8.3355 & 12.5180 & 0.2255 \\
\hline & Paul & 5 & None & 58.2292 & 25.8721 & 0.0000 \\
\hline & & & At most 1 & 6.0517 & 12.5180 & 0.4538 \\
\hline & Romney & 1 & None & 86.7657 & 25.8721 & 0.0000 \\
\hline & & & At most 1 & 5.8113 & 12.5180 & 0.4846 \\
\hline & Thompson, F & 8 & None & 60.8395 & 25.8721 & 0.0000 \\
\hline & & & At most 1 & 19.9372 & 12.5180 & 0.0024 \\
\hline Party & Democratic & 2 & None & 130.0276 & 25.8721 & 0.0000 \\
\hline Winner & & & At most 1 & 4.8289 & 12.5180 & 0.6211 \\
\hline & Field & 5 & None & 25.0531 & 25.8721 & 0.0630 \\
\hline & & & At most 1 & 3.1832 & 12.5180 & 0.8541 \\
\hline
\end{tabular}

Table 11: Cointegration test results. 


\section{B.4 Causality Tests: VECM Restrictions}

\begin{tabular}{|c|c|c|c|c|c|}
\hline Market & Contract & Restriction & $\chi^{2}$ & $p$-value & $\begin{array}{c}\text { Accept/Reject } \\
(5 \% \text { level })\end{array}$ \\
\hline Democratic & Biden & $A(1,1)=0$ & 5.0527 & 0.0246 & Reject \\
\hline \multirow[t]{15}{*}{ Nomination } & & $A(2,1)=0$ & 4.1078 & 0.0427 & Reject \\
\hline & \multirow[t]{2}{*}{ Clinton } & $A(1,1)=0$ & 0.0025 & 0.9604 & Accept \\
\hline & & $A(2,1)=0$ & 14.9567 & 0.0001 & Reject \\
\hline & \multirow[t]{2}{*}{ Dodd } & $A(1,1)=0$ & 26.1808 & 0.0000 & Reject \\
\hline & & $A(2,1)=0$ & 1.7604 & 0.1846 & Accept \\
\hline & \multirow[t]{2}{*}{ Edwards } & $A(1,1)=0$ & 0.1678 & 0.6821 & Accept \\
\hline & & $A(2,1)=0$ & 8.8672 & 0.0029 & Reject \\
\hline & \multirow[t]{2}{*}{ Field } & $A(1,1)=0$ & 3.9653 & 0.0464 & Reject \\
\hline & & $A(2,1)=0$ & 8.7020 & 0.0032 & Reject \\
\hline & \multirow[t]{2}{*}{ Gore } & $A(1,1)=0$ & 1.6388 & 0.2005 & Accept \\
\hline & & $A(2,1)=0$ & 26.2203 & 0.0000 & Reject \\
\hline & \multirow[t]{2}{*}{ Obama } & $A(1,1)=0$ & 2.8282 & 0.0926 & Accept \\
\hline & & $A(2,1)=0$ & 12.2261 & 0.0005 & Reject \\
\hline & \multirow[t]{2}{*}{ Richardson } & $A(1,1)=0$ & 2.4521 & 0.1174 & Accept \\
\hline & & $A(2,1)=0$ & 0.0902 & 0.7640 & Accept \\
\hline \multirow{12}{*}{$\begin{array}{l}\text { Republican } \\
\text { (Period 1) }\end{array}$} & \multirow[t]{2}{*}{ Giuliani } & $A(1,1)=0$ & 9.3688 & 0.0022 & Reject \\
\hline & & $A(2,1)=0$ & 12.0496 & 0.0005 & Reject \\
\hline & \multirow[t]{2}{*}{ McCain } & $A(1,1)=0$ & 5.2443 & 0.0220 & Reject \\
\hline & & $A(2,1)=0$ & 0.8079 & 0.3687 & Accept \\
\hline & \multirow[t]{2}{*}{ Paul } & $A(1,1)=0$ & 12.9595 & 0.0003 & Reject \\
\hline & & $A(2,1)=0$ & 20.4829 & 0.0000 & Reject \\
\hline & \multirow[t]{2}{*}{ Rice } & $A(1,1)=0$ & 13.0994 & 0.0003 & Reject \\
\hline & & $A(2,1)=0$ & 6.4338 & 0.0112 & Reject \\
\hline & \multirow[t]{2}{*}{ Romney } & $A(1,1)=0$ & 5.8186 & 0.0159 & Reject \\
\hline & & $A(2,1)=0$ & 0.7858 & 0.3754 & Accept \\
\hline & \multirow[t]{2}{*}{ Thompson, F } & $A(1,1)=0$ & 24.3540 & 0.0000 & Reject \\
\hline & & $A(2,1)=0$ & 9.5512 & 0.0020 & Reject \\
\hline \multirow{6}{*}{$\begin{array}{l}\text { Republican } \\
\text { (Period 2) }\end{array}$} & Giuliani & $A(1,1)=0$ & 5.1290 & 0.0235 & Reject \\
\hline & & $A(2,1)=0$ & 0.1356 & 0.7127 & Accept \\
\hline & Rice & $A(1,1)=0$ & 0.4135 & 0.5202 & Accept \\
\hline & & $A(2,1)=0$ & 1.2481 & 0.2639 & Accept \\
\hline & Romney & $A(1,1)=0$ & 6.2495 & 0.0124 & Reject \\
\hline & & $A(2,1)=0$ & 2.1759 & 0.1402 & Accept \\
\hline Individual & Clinton & $A(1,1)=0$ & 0.1875 & 0.6650 & Accept \\
\hline Winner & & $A(2,1)=0$ & 12.8795 & 0.0003 & Reject \\
\hline & Edwards & $A(1,1)=0$ & 21.2554 & 0.0000 & Reject \\
\hline & & $A(2,1)=0$ & 0.9732 & 0.3239 & Accept \\
\hline & Field & $A(1,1)=0$ & 26.3952 & 0.0000 & Reject \\
\hline & & $A(2,1)=0$ & 0.9975 & 0.3180 & Accept \\
\hline & Giuliani & $A(1,1)=0$ & 7.7432 & 0.0054 & Reject \\
\hline & & $A(2,1)=0$ & 3.4837 & 0.0620 & Accept \\
\hline & Gore & $A(1,1)=0$ & 9.5401 & 0.0020 & Reject \\
\hline & & $A(2,1)=0$ & 0.3569 & 0.5502 & Accept \\
\hline & Huckabee & $A(1,1)=0$ & 1.8318 & 0.1759 & Accept \\
\hline & & $A(2,1)=0$ & 39.8957 & 0.0000 & Reject \\
\hline & McCain & $A(1,1)=0$ & 13.0525 & 0.0003 & Reject \\
\hline & & $A(2,1)=0$ & 0.5696 & 0.4504 & Accept \\
\hline & Obama & $A(1,1)=0$ & 0.0184 & 0.8920 & Accept \\
\hline & & $A(2,1)=0$ & 10.4997 & 0.0012 & Reject \\
\hline & Paul & $A(1,1)=0$ & 17.6184 & 0.0000 & Reject \\
\hline & & $A(2,1)=0$ & 15.7360 & 0.0001 & Reject \\
\hline & Romney & $A(1,1)=0$ & 13.1094 & 0.0003 & Reject \\
\hline & & $A(2,1)=0$ & 12.1385 & 0.0005 & Reject \\
\hline & Thompson, F & $A(1,1)=0$ & 17.6970 & 0.0000 & Reject \\
\hline & & $A(2,1)=0$ & 0.6672 & 0.4140 & Accept \\
\hline Party & Democrats & $A(1,1)=0$ & 99.2739 & 0.0000 & Reject \\
\hline Winner & & $A(2,1)=0$ & 7.2180 & 0.0072 & Reject \\
\hline & Field & $A(1,1)=0$ & 10.6602 & 0.0011 & Reject \\
\hline & & $A(2,1)=0$ & 3.3617 & 0.0667 & Accept \\
\hline
\end{tabular}

Table 12: Test results for VECM $\alpha$-restrictions. 


\section{B.5 Causality Tests: Granger Causality}

\begin{tabular}{|c|c|c|c|c|c|}
\hline Market & Contract & Alt. Hyp. & $p$-value & d.f. & $\begin{array}{c}\text { Accept/Reject } \\
\text { (5\% level) }\end{array}$ \\
\hline Democratic & Biden & Real g.c. Play & 0.0000 & 8 & Reject \\
\hline \multirow{15}{*}{ Nomination } & & Play g.c. Real & 0.0374 & 8 & Reject \\
\hline & \multirow[t]{2}{*}{ Clinton } & Real g.c. Play & 0.6447 & 1 & Accept \\
\hline & & Play g.c. Real & 0.4681 & 1 & Accept \\
\hline & \multirow[t]{2}{*}{ Dodd } & Real g.c. Play & 0.0024 & 5 & Reject \\
\hline & & Play g.c. Real & 0.0000 & 5 & Reject \\
\hline & \multirow[t]{2}{*}{ Edwards } & Real g.c. Play & 0.0977 & 6 & Accept \\
\hline & & Play g.c. Real & 0.0007 & 6 & Reject \\
\hline & \multirow[t]{2}{*}{ Field } & Real g.c. Play & 0.0711 & 8 & Accept \\
\hline & & Play g.c. Real & 0.0362 & 8 & Reject \\
\hline & \multirow[t]{2}{*}{ Gore } & Real g.c. Play & 0.3030 & 2 & Reject \\
\hline & & Play g.c. Real & 0.9708 & 2 & Reject \\
\hline & \multirow[t]{2}{*}{ Obama } & Real g.c. Play & 0.0021 & 5 & Reject \\
\hline & & Play g.c. Real & 0.0003 & 5 & Reject \\
\hline & \multirow[t]{2}{*}{ Richardson } & Real g.c. Play & 0.0021 & 7 & Reject \\
\hline & & Play g.c. Real & 0.0000 & 7 & Reject \\
\hline \multirow{12}{*}{$\begin{array}{l}\text { Republican } \\
\text { (Period 1) }\end{array}$} & \multirow[t]{2}{*}{ Giuliani } & Real g.c. Play & 0.6923 & 1 & Accept \\
\hline & & Play g.c. Real & 0.9609 & 1 & Accept \\
\hline & \multirow[t]{2}{*}{ McCain } & Real g.c. Play & 0.9059 & 1 & Accept \\
\hline & & Play g.c. Real & 0.5496 & 1 & Accept \\
\hline & \multirow[t]{2}{*}{ Paul } & Real g.c. Play & 0.9532 & 1 & Accept \\
\hline & & Play g.c. Real & 0.0683 & 1 & Accept \\
\hline & \multirow[t]{2}{*}{ Rice } & Real g.c. Play & 0.6356 & 3 & Accept \\
\hline & & Play g.c. Real & 0.0359 & 3 & Reject \\
\hline & \multirow[t]{2}{*}{ Romney } & Real g.c. Play & 0.0740 & 6 & Accept \\
\hline & & Play g.c. Real & 0.0033 & 6 & Reject \\
\hline & \multirow[t]{2}{*}{ Thompson, F } & Real g.c. Play & 0.0230 & 1 & Reject \\
\hline & & Play g.c. Real & 0.0826 & 1 & Accept \\
\hline \multirow{6}{*}{$\begin{array}{l}\text { Republican } \\
\text { (Period 2) }\end{array}$} & Giuliani & Real g.c. Play & 0.1041 & 5 & Accept \\
\hline & & Play g.c. Real & 0.9244 & 5 & Accept \\
\hline & Rice & Real g.c. Play & 0.0289 & 7 & Reject \\
\hline & & Play g.c. Real & 0.0319 & 7 & Reject \\
\hline & Romney & Real g.c. Play & 0.3849 & 2 & Accept \\
\hline & & Play g.c. Real & 0.0107 & 2 & Reject \\
\hline Individual & Clinton & Real g.c. Play & 0.3978 & 1 & Accept \\
\hline Winner & & Play g.c. Real & 0.2046 & 1 & Accept \\
\hline & Edwards & Real g.c. Play & 0.0000 & 4 & Reject \\
\hline & & Play g.c. Real & 0.5027 & 4 & Accept \\
\hline & Field & Real g.c. Play & 0.2443 & 3 & Accept \\
\hline & & Play g.c. Real & 0.4646 & 3 & Accept \\
\hline & Giuliani & Real g.c. Play & 0.4742 & 7 & Accept \\
\hline & & Play g.c. Real & 0.0001 & 7 & Reject \\
\hline & Gore & Real g.c. Play & 0.1702 & 6 & Accept \\
\hline & & Play g.c. Real & 0.0590 & 6 & Accept \\
\hline & Huckabee & Real g.c. Play & 0.1529 & 6 & Accept \\
\hline & & Play g.c. Real & 0.0000 & 6 & Reject \\
\hline & McCain & Real g.c. Play & 0.0022 & 5 & Reject \\
\hline & & Play g.c. Real & 0.2372 & 5 & Accept \\
\hline & Obama & Real g.c. Play & 0.1246 & 4 & Accept \\
\hline & & Play g.c. Real & 0.5407 & 4 & Accept \\
\hline & Paul & Real g.c. Play & 0.1777 & 5 & Accept \\
\hline & & Play g.c. Real & 0.2641 & 5 & Accept \\
\hline & Romney & Real g.c. Play & 0.5000 & 1 & Accept \\
\hline & & Play g.c. Real & 0.1950 & 1 & Accept \\
\hline & Thompson, F & Real g.c. Play & 0.0003 & 8 & Reject \\
\hline & & Play g.c. Real & 0.0007 & 8 & Reject \\
\hline Party & Democrats & Real g.c. Play & 0.0197 & 2 & Reject \\
\hline Winner & & Play g.c. Real & 0.5233 & 2 & Accept \\
\hline & Field & Real g.c. Play & 0.4478 & 5 & Accept \\
\hline & & Play g.c. Real & 0.6036 & 5 & Accept \\
\hline
\end{tabular}

Table 13: Granger Causality test results. (g.c.: Granger causes; d.f.: degrees of freedom). 


\section{B.6 McCain, period 2}

\begin{tabular}{|c|c|c|c|c|c|c|}
\hline \multirow[b]{2}{*}{ Contract } & \multirow{2}{*}{$\begin{array}{l}\text { Lags } \\
\text { (AIC) }\end{array}$} & \multirow[b]{2}{*}{$t$-stat. } & \multicolumn{3}{|c|}{ Critical value } & \multirow[b]{2}{*}{ Sig. } \\
\hline & & & $1 \%$ & $5 \%$ & $10 \%$ & \\
\hline Real-money & 0 & -3.7399 & -3.5155 & -2.8986 & -2.5866 & $* * *$ \\
\hline Play-money & 0 & -4.3371 & -3.5178 & -2.8996 & -2.5871 & $* * *$ \\
\hline \multicolumn{7}{|l|}{ Granger causality test } \\
\hline Null Hyp. & Lags (AIC) & $F$-stat. & $p$-value & & & \\
\hline Real does not g.c. Play & 1 & 1.3193 & 0.2544 & & & \\
\hline Play does not g.c. Real & 1 & 1.2801 & 0.2615 & & & \\
\hline
\end{tabular}

Table 14: Test results on McCain in period two. (g.c: Granger causes; **: $1 \%$ level). 